Article

\title{
The Interaction of Vitamin D and Corticosteroids: A Mortality Analysis of 26,508 Veterans Who Tested Positive for SARS-CoV-2
}

\author{
Jimmy T. Efird ${ }^{1, *}$, Ethan J. Anderson ${ }^{2}$, Charulata Jindal ${ }^{3}$, Thomas S. Redding ${ }^{1}$, Andrew D. Thompson ${ }^{1}$, \\ Ashlyn M. Press ${ }^{1}{ }^{(\mathbb{D}}$, Julie Upchurch ${ }^{1}{ }^{1}$, Christina D. Williams ${ }^{1,4,5}$, Yuk Ming Choi ${ }^{6}$ and Ayako Suzuki ${ }^{1,7,8}$
}

check for updates

Citation: Efird, J.T.; Anderson, E.J.; Jindal, C.; Redding, T.S.; Thompson, A.D.; Press, A.M.; Upchurch, J.; Williams, C.D.; Choi, Y.M.; Suzuki, A. The Interaction of Vitamin D and Corticosteroids: A Mortality Analysis of 26,508 Veterans Who Tested Positive for SARS-CoV-2. Int. J. Environ. Res. Public Health 2022, 19 , 447. https://doi.org/10.3390/ ijerph19010447

Academic Editor: Oliver Grundmann

Received: 5 December 2021

Accepted: 28 December 2021

Published: 31 December 2021

Publisher's Note: MDPI stays neutral with regard to jurisdictional claims in published maps and institutional affiliations.

Copyright: (C) 2021 by the authors. Licensee MDPI, Basel, Switzerland. This article is an open access article distributed under the terms and conditions of the Creative Commons Attribution (CC BY) license (https:// creativecommons.org/licenses/by/ $4.0 /)$.
1 Cooperative Studies Program Epidemiology Center, Durham VA Health Care System, Durham, NC 27705, USA; thomas.redding28@va.gov (T.S.R.); andrew.thompson3@va.gov (A.D.T.); ashlyn.press@va.gov (A.M.P.); julie.upchurch@va.gov (J.U.); christina.williams4@va.gov (C.D.W.); ayako.suzuki@duke.edu (A.S.)

2 College of Pharmacy, University of Iowa, Iowa City, IA 52242, USA; ethan-anderson@uiowa.edu

3 Harvard Medical School, Harvard University, Boston, MA 02115, USA; charujindal@gmail.com

4 Department of Medicine, Duke University, Durham, NC 27710, USA

5 Duke Cancer Institute, Duke University, Durham, NC 27710, USA

6 Signify Health, Dallas, TX 75244, USA; ychoi@signifyhealth.com

7 Division of Gastroenterology, Duke University, Durham, NC 27710, USA

8 The Division of Gastroenterology, Durham VA Medical Center, Durham, NC 27705, USA

* Correspondence: jimmy.efird@va.gov; Tel.: +1-(650)-248-8282

Abstract: This data-based cohort consisted of 26,508 (7\%) United States veterans out of the 399,290 who tested positive for SARS-CoV-2 from 1 March to 10 September 2020. We aimed to assess the interaction of post-index vitamin D (Vit D) and corticosteroid (CRT) use on 30-day mortality among hospitalized and non-hospitalized patients with coronavirus disease 2019 (COVID-19). Combination Vit D and CRT drug use was assessed according to four multinomial pairs $(-|+,-|-,+|+,+|-)$. Respective categorical effects were computed on a log-binomial scale as adjusted relative risk (aRR). Approximately $6 \%$ of veterans who tested positive for SARS-CoV-2 died within 30 days of their index date. Among hospitalized patients, a significantly decreased aRR was observed for the use of Vit $\mathrm{D}$ in the absence of CRTs relative to patients who received CRTs but not Vit D ( $\mathrm{aRR}=0.30$; multiplicity corrected, $p=0.0004$ ). Among patients receiving systemically administered CRTs (e.g., dexamethasone), the use of Vit $\mathrm{D}$ was associated with fewer deaths in hospitalized patients $(\mathrm{aRR}=0.51)$ compared with non-hospitalized patients $(\mathrm{aRR}=2.5)$ ( $P$-for-Interaction $=0.0071)$. Evaluating the effect of modification of these compounds in the context of hospitalization may aid in the management of COVID-19 and provide a better understanding of the pathophysiological mechanisms underlying this and future infectious disease outbreaks.

Keywords: anti-inflammatory; corticosteroids; COVID-19; cytokine storm; SARS-CoV-2; vitamin D; veterans

\section{Introduction}

Vitamin D (Vit D) is an oxysterol hormone with important immunomodulatory and antiviral properties [1-8]. Even though this vitamin is often recommended as a nutritional supplement in treatment guidelines and prescribed for the management of coronavirus disease 2019 (COVID-19) [9-12], several studies have yielded divergent or inconclusive results [13-54].

The complex interaction of Vit D and corticosteroids (CRTs) in vivo may partially explain the conflicting outcomes observed in the COVID-19 literature, and previous studies on Vit D have been insufficiently powered to detect this interaction [55-59]. Glucocorticoids can inactivate Vit D by upregulating Vit D receptor (VDR)-mediated 24-hydroxylase 
transcription through the cooperative relationship of CCAAT-enhancer-binding proteins $(\mathrm{C} / \mathrm{EBP} \beta)$ and glucocorticoid receptors (GRs) [60]. This mechanism is likely the reason why CRT use in a nationally representative cohort study was associated with a two-fold reduction in endogenous Vit D levels [61]. Indeed, suboptimal concentrations of serum 25-hydroxyvitamin $\mathrm{D} 3\left(25(\mathrm{OH}) \mathrm{D}_{3}\right)$ in the order of $-0.5 \mathrm{ng} / \mathrm{mL}$ have been linked with the use of glucocorticoids such as dexamethasone, methylprednisolone, and prednisone [62,63].

However, these Vit D-lowering effects of CRTs may be countered by the fact that clinical doses of dexamethasone enhance the effects of $25(\mathrm{OH}) \mathrm{D}_{3}$, thus inducing VDR expression in immune cells [64-66]. Administration of Vit D purportedly reverses the induction of interleukin 10 (IL-10)-secreting regulatory $\mathrm{T}$ cells in glucocorticoid-resistant patients, a mechanism particularly beneficial in the context of COVID-19 [67]. Vit D has also been shown to have a synergistic anti-inflammatory effect with CRTs by facilitating glucocorticoid induction of mitogen-activated protein kinase (MAPK) phosphatase 1 (MKP-1) and IL-10 in peripheral blood mononuclear cells (PBMCs) [68]. Granulocyte-macrophage colony-stimulating factor (GM-CSF) found in culture supernatants from clusters of differentiation 14-negative (CD14-) cells and mediator complex subunit 14 (MED14) have been recognized as significant factors in this process, effectively reducing the dose of glucocorticoids needed to mitigate inflammatory effects [69]. Concurrently with CRTs, Vit $\mathrm{D}$ is thought to prompt a tolerogenic dendritic cell phenotype with immunomodulatory action $[70,71]$.

The results of a meta-analysis suggest that Vit D supplementation (varying doses and frequencies across studies) improves COVID-19 clinical response, but only in patients receiving the drug after diagnosis of COVID-19 [21]. Systemic CRT use increased by $19 \%$ among hospitalized adults during the COVID-19 pandemic based on evidence that these compounds reduced 28-day mortality in hospitalized patients requiring supplemental oxygen or mechanical ventilation $[72,73]$. However, among those not receiving respiratory support, the administration of CRTs was consistent with possible deleterious effects. That is, if CRTs are delivered when control of viral replication is critical, blunting the inflammatory response may be more harmful than helpful [73].

In this observational analysis, we hypothesized that Vit D and CRTs interact through various putative mechanisms to affect overall 30 -day mortality among patients testing positive for SARS-CoV-2 (Figure 1). Furthermore, this effect is postulated to be dependent on hospitalization status as a surrogate marker of disease severity. 
Vitamin D 25(OH) $\mathrm{D}_{3}$ - calcidiol

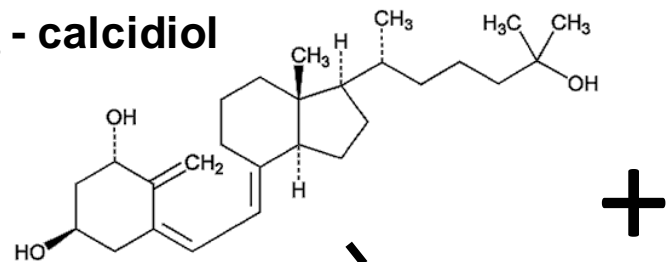

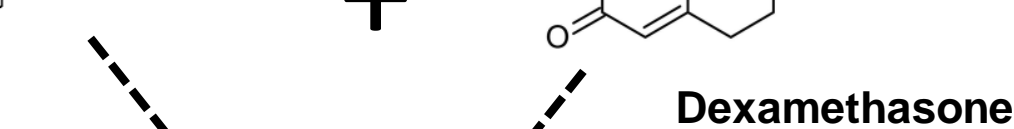
$(\underbrace{\prime \prime 2}_{1}$

Dexamethasone

\section{$\uparrow \downarrow$ Cyto/Chemokine gene expression}

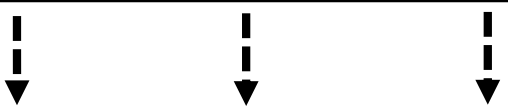

\section{Augmented CRT therapeutic effects} \& Improved Survival

Figure 1. Interaction and outcomes of vitamin D and corticosteroid administration in COVID19 patients. A cursory overview of various mechanisms by which corticosteroids (i.e., dexamethasone) and vitamin D interact synergistically in patients with COVID-19 is shown in the schematic above, along with the outcomes of this interaction as reported in the present study. $\quad \mathrm{CRT}=$ corticosteroid; $\mathrm{PBMCs}=$ human peripheral blood mononuclear cells; $\mathrm{VDR}=$ vitamin $\mathrm{D}$ receptor; $25(\mathrm{OH}) \mathrm{D}_{3}=25$-hydroxyvitamin $\mathrm{D} 3$.

\section{Materials and Methods}

\subsection{Study Design and Data Source}

Data for this study were obtained from the United States (US) Department of Veterans Affairs (VA) COVID-19 Shared Data Resource (CSDR) and related data in the national Corporate Data Warehouse (CDW), with details described in our previous publication [74]. The VA Health Care System consists of $\sim 171$ medical centers and 1112 outpatient sites of care. Approval for the study protocol was provided by the Durham VA Health Care System Institutional Review Board.

\subsection{Cohort Definition}

The cohort consisted of veterans who tested positive for SARS-CoV-2 from 1 March to 10 September 2020. During the study period, COVID-19 testing was restricted to participants who were symptomatic for COVID-19 or were required to have a SARS-CoV-2 test for hospitalization. Hospitalized and non-hospitalized patients, males and females, and all race/ethnicity categories were included in this analysis to increase the generalizability of the study findings. We report the first SARS-CoV-2-positive collection date as the index date and only considered this first event. 


\subsection{Case Definition}

Cases were identified using the VA CSDR [75]. We defined SARS-CoV-2-positive veterans using all available SARS-CoV-2 nucleic acid amplification (NAAT) and antigen tests, excluding antibody tests. Some patients in the VA Health Care System were tested or diagnosed outside of the VA, with special informatics tools used to aid the identification of COVID-19 cases [76]. However, we did not include these patients in the analyses focusing on veterans who were tested at any of the VA facilities.

\subsection{Study Variables}

The primary outcome variable was 30-day overall mortality after the first positive SARS-CoV-2 test. Hospitalizations were defined as occurring in the post-index period and typically entailed patients who experienced severe disease presentation, requiring close monitoring and intensive care [77].

Electronic outpatient and inpatient prescription and dispense records were reviewed to determine the systemic use of Vit D and CRTs. By consensus of our clinical team, the post-index use of these compounds was defined as drugs administered at least $50 \%$ of the time ( $\geq 7$ days or half of the survival time) within 2 weeks post-SARS-CoV-2 testing. Length of hospital stay corresponded to only the first hospitalization happening within 30 days after the SARS-CoV-2 test date. Information and definitions regarding the covariates used in the analyses were published previously [74].

Non-VA medications, including prescriptions from non-VA providers and over-thecounter medications, were recorded in the electronic health records through medication reconciliation performed at clinical encounters. Among non-hospitalized patients, Vit D supplements were either from VA prescriptions, non-VA prescriptions, or over-thecounter supplements. We counted all available Vit D supplements, including calcitriol. Inhaled CRTs such as beclomethasone, budesonide, ciclesonide, flunisolide, fluticasone, or mometasone were not considered in the current analysis.

\subsection{Statistical Analysis}

Study characteristics are expressed as frequency and percentage for categorical variables and median and interquartile range (IQR) for continuous variables. A weighted average of stratum-specific estimates on the log-binomial scale was used to approximate the adjusted relative risk (aRR) for 30-day mortality [78]. Final models were adjusted for age categories, race, sex, region, month of diagnosis, body mass index (BMI) categories, current smoking, alcohol use disorder, and Charlson Comorbidity Index score categories. An unrestricted additive test for interaction was used to test for heterogeneity of relative effect estimates $\left(\Delta_{\mathrm{aRR}} \%\right)$ on the logarithmic scale $[79,80]$. Vertical and horizontal interactions were similarly assessed, appropriately adjusting confidence intervals to account for the two estimates of $\Delta_{\mathrm{aRR}} \%$ [81].

To assess the multinomial synergistic drug effects for Vit D and CRT, we created four categories for each pair to respectively denote single and combination drug use $(-\mid+$, $-|-,+|+,+\mid-)$. The referent group $(-\mid+)$ was used in our key analyses to illustrate the maximum difference in effect sizes and linearity of these effects among the hospitalized versus non-hospitalized patients. However, selected comparisons also were conducted with $(-\mid-)$ as the referent group. Multiplicity correction (MC) was performed using the Hochberg-Bonferroni procedure, accounting for a common referent group [82].

The expectation-maximization algorithm was used to find maximum a posteriori estimates of model parameters, dependent on unobserved latent variables [83]. Linearization and normalization of data elements were performed when appropriate. Study results were rounded using the Goldilocks (Efron-Whittemore) method [80]. $p$-values < 0.05 were considered statistically significant. All the analyses were performed using SAS version 9.4 (SAS Institute, Cary, NC, USA). 


\section{Results}

A total of 26,508 veterans tested positive for SARS-CoV-2, with a 30-day mortality rate of $6 \%$ (Table 1). Approximately $93 \%$ of deaths occurred among those $>60$ years of age. Most participants were male (89\%), non-Latinx (83\%), overweight $(82 \%)$, White $(59 \%)$, and $\leq 60$ years of age (52\%). Few patients were hospitalized for more than 2 weeks $(7 \%)$ and less than $5 \%$ received mechanical ventilation. Commonly reported comorbidities were hypertension (55\%), hyperlipidemia (52\%), and mental illness (49\%). Slightly more Black veterans than White veterans received post-index Vit D (5\% versus 3\%) and, similarly, CRTs (23\% versus $20 \%$ ). Only $1 \%$ of the cohort received a combination of Vit D and CRTs. Approximately $76 \%$ of the sample did not use either drug.

Table 1. Selected characteristics of SARS-CoV-2-positive veterans $(N=26,508)$.

\begin{tabular}{|c|c|c|c|c|c|}
\hline \multirow[t]{2}{*}{ Characteristic } & \multicolumn{4}{|c|}{$\begin{array}{c}\text { Post-Index Medication Usage * } \\
\text { (Vitamin D I Corticosteroids) } \\
\text { n (\%), Median (IQR) }\end{array}$} & \multirow[t]{2}{*}{$\begin{array}{c}\text { 30-Day Mortality } \\
\text { n (\%), Median (IQR) }\end{array}$} \\
\hline & $(-1+)$ & $(-1-)$ & $(+1+)$ & $(+1-)$ & \\
\hline $\mathrm{N}$ (\% of total sample size) & $5355(20)$ & $20,134(76)$ & $283(1)$ & $736(3)$ & $1612(6)$ \\
\hline Age (y) & $64(21)$ & $58(27)$ & $66(16)$ & $63(20)$ & $76(16)$ \\
\hline$\leq 30$ & $154(3)$ & $1425(7)$ & $5(2)$ & $14(2)$ & $0(0)$ \\
\hline $31-40$ & $455(9)$ & $3058(15)$ & $12(4)$ & $59(8)$ & $3(<1)$ \\
\hline $41-50$ & $598(11)$ & $2725(14)$ & $26(9)$ & $84(11)$ & $25(2)$ \\
\hline $51-60$ & $976(18)$ & $3864(19)$ & 49 (17) & $165(22)$ & $80(5)$ \\
\hline $61-70$ & $1362(25)$ & $4101(20)$ & $88(31)$ & $179(24)$ & $328(20)$ \\
\hline $71-80$ & $1301(24)$ & 3410 (17) & $76(27)$ & $177(24)$ & $569(35)$ \\
\hline $81-90$ & $401(7)$ & $1151(6)$ & $19(7)$ & $37(5)$ & $401(25)$ \\
\hline$>90$ & $108(2)$ & $400(2)$ & $8(3)$ & $21(3)$ & $206(13)$ \\
\hline Male & $4831(90)$ & $17,970(89)$ & $240(85)$ & $618(84)$ & $1575(98)$ \\
\hline \multicolumn{6}{|l|}{ Race } \\
\hline White & 3047 (57) & $12,070(60)$ & $147(52)$ & $392(53)$ & $1009(63)$ \\
\hline Black & $2101(39)$ & $7257(36)$ & $129(46)$ & $328(45)$ & $547(34)$ \\
\hline Asian & $59(1)$ & $226(1)$ & $1(<1)$ & $3(<1)$ & $15(1)$ \\
\hline AIAN & $50(1)$ & $166(1)$ & $0(0)$ & $2(<1)$ & $16(1)$ \\
\hline NHOPI & $51(1)$ & $207(1)$ & $2(1)$ & $7(1)$ & $13(1)$ \\
\hline Multiracial & $47(1)$ & $208(1)$ & $4(1)$ & $4(1)$ & $12(1)$ \\
\hline Latinx & $790(15)$ & $3536(18)$ & $25(9)$ & $102(14)$ & $154(10)$ \\
\hline $\operatorname{BMI}\left(\mathrm{kg} / \mathrm{m}^{2}\right)$ & $31[8.3]$ & 30 [7.7] & $30[8.5]$ & $30[8.6]$ & $27[9]$ \\
\hline Underweight $(<18.5)$ & $100(2)$ & $243(1)$ & $7(2)$ & $10(1)$ & $73(5)$ \\
\hline Normal (18.5-24.9) & $883(16)$ & 3403 (17) & $45(16)$ & $127(17)$ & $489(30)$ \\
\hline Overweight (25-29.9) & $1655(31)$ & $6678(33)$ & $83(29)$ & $249(34)$ & $490(30)$ \\
\hline Class-I Obese (30-34.9) & $1462(27)$ & $5748(29)$ & $90(32)$ & $178(24)$ & $304(19)$ \\
\hline Class-II Obese (35-39.9) & $777(15)$ & $2614(13)$ & $34(12)$ & $104(14)$ & $159(10)$ \\
\hline Class-III Obese (40-44.9) & $323(6)$ & $984(5)$ & $18(6)$ & $35(5)$ & $55(3)$ \\
\hline Super Obese $(\geq 45)$ & $155(3)$ & $464(2)$ & $6(2)$ & $33(4)$ & $42(3)$ \\
\hline Alcohol Use Disorder & $671(13)$ & $2683(13)$ & $37(13)$ & $118(16)$ & $163(10)$ \\
\hline \multicolumn{6}{|l|}{ Smoker $\S$} \\
\hline Never & $2413(45)$ & $10,167(51)$ & $137(48)$ & $381(52)$ & $644(40)$ \\
\hline Former & $2406(45)$ & $7623(38)$ & $118(42)$ & $297(40)$ & $858(53)$ \\
\hline Current & $536(10)$ & $2344(12)$ & $28(10)$ & $58(8)$ & $110(7)$ \\
\hline Hospitalization & $3149(59)$ & $4340(22)$ & $164(58)$ & $192(26)$ & $1113(69)$ \\
\hline
\end{tabular}


Table 1. Cont.

\begin{tabular}{|c|c|c|c|c|c|}
\hline \multirow[t]{2}{*}{ Characteristic } & \multicolumn{4}{|c|}{$\begin{array}{c}\text { Post-Index Medication Usage * } \\
\text { (Vitamin D I Corticosteroids) } \\
\text { n (\%), Median (IQR) }\end{array}$} & \multirow[t]{2}{*}{$\begin{array}{c}\text { 30-Day Mortality } \\
\text { n (\%), Median (IQR) }\end{array}$} \\
\hline & $(-1+)$ & $(-1-)$ & $(+1+)$ & $(+1-)$ & \\
\hline Length of Stay (days) & $8[11]$ & $6[10]$ & $6[12]$ & $5[11]$ & $9[9]$ \\
\hline$\leq 7^{\sim}$ & $3751(70)$ & $18,398(91)$ & $209(74)$ & $669(91)$ & $946(59)$ \\
\hline$>7-14$ & $790(15)$ & $854(4)$ & $29(10)$ & $28(4)$ & $388(24)$ \\
\hline$>14$ & $814(15)$ & $882(4)$ & $45(16)$ & $39(5)$ & $278(17)$ \\
\hline Mechanical Ventilation & $673(13)$ & $465(2)$ & $30(11)$ & $14(2)$ & $598(37)$ \\
\hline \multicolumn{6}{|l|}{ Location (USA) } \\
\hline Pacific-West/Mountain & $971(18)$ & $3996(20)$ & $42(15)$ & $97(13)$ & $231(14)$ \\
\hline Mid-West/Continental & $1053(20)$ & $4175(21)$ & $42(15)$ & $93(13)$ & $251(16)$ \\
\hline Southeast & $2598(49)$ & $8111(40)$ & $180(64)$ & $442(60)$ & $592(37)$ \\
\hline Northeast & $733(14)$ & $3852(19)$ & $19(7)$ & $104(14)$ & $538(33)$ \\
\hline \multicolumn{6}{|l|}{ Time (Index, 3/1-9/10) } \\
\hline March & $362(7)$ & $1668(8)$ & $17(6)$ & $54(7)$ & $253(16)$ \\
\hline April & $512(10)$ & $2916(14)$ & $26(9)$ & $97(13)$ & $445(28)$ \\
\hline May & $297(6)$ & $1730(9)$ & $12(4)$ & $61(8)$ & $190(12)$ \\
\hline June & $953(18)$ & $3592(18)$ & $42(15)$ & $122(17)$ & $205(13)$ \\
\hline July & $2155(40)$ & $7136(35)$ & $114(40)$ & $277(38)$ & $315(20)$ \\
\hline August & 998 (19) & $2950(15)$ & $68(24)$ & $121(16)$ & $192(12)$ \\
\hline September & $78(1)$ & $142(1)$ & $4(1)$ & $4(1)$ & $12(<1)$ \\
\hline \multicolumn{6}{|l|}{$\mathrm{CCI}$} \\
\hline 0 & $2198(41)$ & $11,712(58)$ & $93(33)$ & $329(45)$ & 407 (25) \\
\hline $1-2$ & $1978(37)$ & $6032(30)$ & $115(41)$ & $291(40)$ & $572(35)$ \\
\hline $3-4$ & $766(14)$ & $1640(8)$ & 48 (17) & $77(10)$ & $391(24)$ \\
\hline $5^{+}$ & $413(8)$ & $750(4)$ & $27(10)$ & $39(5)$ & $242(15)$ \\
\hline \multicolumn{6}{|l|}{ Comorbidity } \\
\hline Asthma & $591(11)$ & $1039(5)$ & $29(10)$ & $56(8)$ & $74(5)$ \\
\hline Atherosclerosis & $1830(34)$ & $4551(23)$ & $112(40)$ & $207(28)$ & $872(54)$ \\
\hline Cancer & 885 (17) & 2095 (10) & $80(28)$ & 137 (19) & $391(24)$ \\
\hline Chronic Kidney Disease & $1173(22)$ & $2664(13)$ & $77(27)$ & $121(16)$ & $612(38)$ \\
\hline Chronic Liver Disease & $145(3)$ & $408(2)$ & $13(5)$ & $22(3)$ & $68(4)$ \\
\hline $\mathrm{CHF}$ & $900(17)$ & $1930(10)$ & $52(18)$ & $89(12)$ & $452(28)$ \\
\hline COPD & $1307(24)$ & $2188(11)$ & $79(28)$ & $108(15)$ & $472(29)$ \\
\hline Diabetes (Type II) & $2108(39)$ & $6116(30)$ & $122(43)$ & $307(42)$ & $813(50)$ \\
\hline Hyperlipidemia & $3227(60)$ & $10,032(50)$ & $183(65)$ & $466(63)$ & $1047(65)$ \\
\hline Hypertension & $3523(66)$ & $10,461(52)$ & $209(74)$ & $501(68)$ & $1242(77)$ \\
\hline Mental Illness & $2716(51)$ & $9662(48)$ & $148(52)$ & $409(56)$ & $709(44)$ \\
\hline Sleep Disorder & $1828(34)$ & $5111(25)$ & $99(35)$ & $214(29)$ & $416(26)$ \\
\hline Substance Abuse & $1194(22)$ & $4222(21)$ & $62(22)$ & $173(24)$ & 307 (19) \\
\hline
\end{tabular}

Referent is the complement group. * Systemic administration by mouth or intramuscular injection. $\S$ Cigarettes $\sim$ Includes non-hospitalized participants with zero length of stay. AIAN = American Indian and Alaska Native, $\mathrm{BMI}=$ body mass index $\mathrm{CCI}=$ Charlson Comorbidity Index $\mathrm{CHF}=$ congestive heart failure; $\mathrm{COPD}=$ chronic obstructive pulmonary disease; $\mathrm{IQR}=$ interquartile range; $\mathrm{kg}$ = kilograms; $\mathrm{m}=$ meters; NHOPI = Native Hawaiian or Pacific Islander; USA = United States of America; $y=$ years.

Compared with the use of post-index CRT use alone $(-I+)$, the combination therapy of Vit D and CRTs $(+\mid+)$ as well as the use of post-index Vit D alone $(+\mid-)$ were logarithmically associated with $98 \%\left(P_{\mathrm{mc}}=0.031\right)$ and $223 \%\left(P_{\mathrm{mc}}=0.0004\right)$ reduced 30-day mortality adjusted risk among those hospitalized, respectively (Table 2). For this group of hospitalized patients, an aRR of $1.5\left(95 \% \mathrm{CI}=1.3-1.7 ; P_{\mathrm{mc}}<0.0001\right)$ was observed for CRT use alone $(-\mid+)$ compared with the use of neither compound $(-\mid-)$ (not shown in tables). Analogously, the aRR for Vit D use alone $(+\mid-)$ versus neither compound $(-\mid-)$ was 0.47 $\left(95 \% \mathrm{CI}=0.25-0.90 ; P_{\mathrm{mc}}=0.022\right)$. 
Table 2. Adjusted risk for non-survivors and survivors among SARS-CoV-2-positive veterans by indicated post-index medication use and hospitalization status.

\begin{tabular}{|c|c|c|c|c|c|}
\hline \multirow{2}{*}{\multicolumn{2}{|c|}{$\begin{array}{c}\text { Post-Index } \\
\text { Medication * }\end{array}$}} & \multirow{2}{*}{$\begin{array}{c}\text { Non } \\
\text { Survivors } \\
\text { n (\%) }\end{array}$} & \multirow{2}{*}{$\begin{array}{c}\text { Survivors } \\
\text { n (\%) }\end{array}$} & \multicolumn{2}{|c|}{ Multiplicity Corrected $\ddagger$} \\
\hline & & & & $\operatorname{aRR}(95 \% \mathrm{CI})^{\dagger}$ & $p$-Value \\
\hline \multicolumn{6}{|c|}{ Hospitalized $(N=7845)$} \\
\hline Vitamin D & Corticosteroids & & & & \\
\hline- & + & $534(48)$ & 2615 (39) & 1.0 Referent & - \\
\hline- & - & $553(50)$ & $3787(56)$ & $0.66(0.58-0.74)$ & $<0.0001$ \\
\hline+ & + & $15(1)$ & $149(2)$ & $0.51(0.27-0.94)$ & 0.031 \\
\hline+ & - & $11(1)$ & $181(3)$ & $0.30(0.16-0.58)$ & 0.0004 \\
\hline \multicolumn{6}{|c|}{ Non-hospitalized $(N=18,663)$} \\
\hline Vitamin D & Corticosteroids & & & & \\
\hline- & + & $69(14)$ & 2137 (12) & 1.0 Referent & - \\
\hline- & - & $413(83)$ & $15,381(85)$ & $0.94(0.71-1.2)$ & 0.66 \\
\hline+ & + & $6(1)$ & $113(1)$ & $2.5(0.90-7.1)$ & 0.078 \\
\hline+ & - & $11(2)$ & $533(3)$ & $0.48(0.22-1.1)$ & 0.078 \\
\hline
\end{tabular}

Non-referent group of the indicated comparison factor. * Systemic administration by mouth or intramuscular injection. ${ }^{+}$Adjusted for Age $(\leq 60,61-70,71-80,>80)$, Alcohol Use Disorder (Yes, No), BMI $(<18.5,18.5-24.9$, $25-29.9, \geq 30$ ), Charlson Comorbidity Index $\left(0,1-2,3-4,5^{+}\right)$, Current Smoker (Yes, No), Location (Pacific-Mountain, Mid-West/Continental, East Coast), Race (White, Black, Other Race), Sex (Male, Female), and Time (March, AprilSeptember). $¥$ Subset analyses corrected for multiplicity using the Hochberg step-up procedure for multinomial comparisons. $\mathrm{aRR}=$ Adjusted relative risk; $\mathrm{BMI}=$ body mass index $\left(\mathrm{kg} / \mathrm{m}^{2}\right) ; \mathrm{CI}=$ confidence interval.

Among non-hospitalized patients, Vit $\mathrm{D}$ use alone showed a tendency toward a decreased risk $\left(\mathrm{aRR}=0.48,95 \% \mathrm{CI}=0.22-1.1, P_{\mathrm{mc}}=0.078\right)($ Table 2$)$. A borderline significant risk increase was observed for the combined use of Vit D and CRTs $(+I+)$ relative to the use of CRTs without Vit D $(-1+)\left(\mathrm{aRR}=2.5,95 \% \mathrm{CI}=0.90-7.1 ; P_{\mathrm{mc}}=0.078\right)$. Comparable risk effects were observed for the subset of Black and White hospitalized patients (Tables 3 and 4).

Table 3. Adjusted risk at 30 days for non-survivors and survivors among hospitalized SARS-CoV-2positive veterans by indicated post-index medication use and race.

\begin{tabular}{|c|c|c|c|c|c|}
\hline \multirow{2}{*}{\multicolumn{2}{|c|}{$\begin{array}{c}\text { Post-Index } \\
\text { Medication * }\end{array}$}} & \multirow{2}{*}{$\begin{array}{c}\text { Non } \\
\text { Survivors } \\
\text { n (\%) }\end{array}$} & \multirow{2}{*}{$\begin{array}{c}\text { Survivors } \\
\text { n (\%) }\end{array}$} & \multicolumn{2}{|c|}{ Multiplicity Corrected $\ddagger$} \\
\hline & & & & $\operatorname{aRR}(95 \% \mathrm{CI})^{\dagger}$ & $p$-Value \\
\hline \multicolumn{6}{|c|}{ Black $(N=3281)$} \\
\hline Vitamin D & Corticosteroids & & & & \\
\hline- & + & $185(45)$ & $1089(38)$ & 1.0 Referent & - \\
\hline - & - & $215(52)$ & $1633(57)$ & $0.69(0.55-0.86)$ & 0.0009 \\
\hline+ & + & $5(1)$ & $70(2)$ & $0.44(0.09-0.2 .0)$ & 0.29 \\
\hline+ & - & $5(1)$ & $79(3)$ & $0.34(0.12-0.98)$ & 0.047 \\
\hline \multicolumn{6}{|c|}{ White $(N=4291)$} \\
\hline Vitamin D & Corticosteroids & & & & \\
\hline- & + & $329(50)$ & $1434(40)$ & 1.0 Referent & - \\
\hline- & - & $318(48)$ & $2020(56)$ & $0.65(0.55-0.76)$ & $<0.0001$ \\
\hline+ & + & $9(1)$ & $76(2)$ & $0.50(0.26-0.96)$ & 0.036 \\
\hline+ & - & $6(1)$ & $99(3)$ & $0.29(0.12-0.66)$ & 0.0032 \\
\hline
\end{tabular}

Non-referent group of the indicated comparison factor. * Systemic administration by mouth or intramuscular injection. ${ }^{\dagger}$ Adjusted for Age $(\leq 60,61-70,71-80,>80)$, Alcohol Use Disorder (Yes, No), BMI $(<18.5,18.5-24.9$, 25-29.9, $\geq 30$ ), Charlson Comorbidity Index $\left(0,1-2,3-4,5^{+}\right)$, Current Smoker (Yes, No), Location (Pacific-Mountain, Mid-West/Continental, East Coast), Sex (Male, Female), and Time (March, April-September). Subset analyses corrected for multiplicity using the Hochberg step-up procedure for multinomial comparisons. aRR = Adjusted relative risk; $\mathrm{BMI}=$ body mass index $\left(\mathrm{kg} / \mathrm{m}^{2}\right) ; \mathrm{CI}=$ confidence interval. 
Table 4. Adjusted risk at 30 days for non-survivors and survivors among non-hospitalized SARSCoV-2-positive veterans by indicated post-index medication use and race.

\begin{tabular}{|c|c|c|c|c|c|}
\hline \multirow{2}{*}{\multicolumn{2}{|c|}{$\begin{array}{l}\text { Post-Index } \\
\text { Medication * }\end{array}$}} & \multirow{2}{*}{$\begin{array}{c}\text { Non } \\
\text { Survivors } \\
\text { n (\%) }\end{array}$} & \multirow{2}{*}{$\begin{array}{c}\text { Survivors } \\
\text { n (\%) }\end{array}$} & \multicolumn{2}{|c|}{ Multiplicity Corrected $\ddagger$} \\
\hline & & & & $\operatorname{aRR}(95 \% C I){ }^{\dagger}$ & $p$-Value \\
\hline \multicolumn{6}{|c|}{ Black $(N=6534)$} \\
\hline Vitamin D & Corticosteroids & & & & \\
\hline- & + & $16(12)$ & $811(13)$ & 1.0 Referent & - \\
\hline- & - & $116(85)$ & $5293(83)$ & $1.2(0.68-2.0)$ & 0.56 \\
\hline+ & + & $0(0)$ & $54(<1)$ & $\infty$ & $\infty$ \\
\hline+ & - & $5(4)$ & $239(4)$ & $0.93(0.24-3.6)$ & 0.92 \\
\hline \multicolumn{6}{|c|}{ White $(N=11,365)$} \\
\hline Vitamin D & Corticosteroids & & & & \\
\hline- & + & $51(15)$ & $1233(11)$ & 1.0 Referent & - \\
\hline- & - & $284(82)$ & $9448(86)$ & $0.86(0.42-1.7)$ & 0.67 \\
\hline+ & + & $6(2)$ & $56(1)$ & $2.7(0.77-9.2)$ & 0.12 \\
\hline+ & - & $6(2)$ & $281(3)$ & $0.35(0.10-1.2)$ & 0.093 \\
\hline
\end{tabular}

Non-referent group of the indicated comparison factor. * Systemic administration by mouth or intramuscular injection. ${ }^{+}$Adjusted for Age $(\leq 60,61-70,71-80,>80)$, Alcohol Use Disorder (Yes, No), BMI $(<18.5,18.5-24.9,25-29.9, \geq 30)$, Charlson Comorbidity Index $\left(0,1-2,3-4,5^{+}\right)$, Current Smoker (Yes, No), Location (Pacific-Mountain, Mid-West/Continental, East Coast), Sex (Male, Female), and Time (March, AprilSeptember). $\ddagger$ Subset analyses corrected for multiplicity using the Hochberg step-up procedure for multinomial comparisons. $\infty=$ non-convergent (zero cell). aRR = Adjusted relative risk; $\mathrm{BMI}=$ body $\operatorname{mass}$ index $\left(\mathrm{kg} / \mathrm{m}^{2}\right)$; $\mathrm{CI}=$ confidence interval.

A significant mortality interaction was observed for the effect of Vit D use in hospitalized versus non-hospitalized patients who received post-index CRTs $(P$-for-interaction $\left.\left(P_{I n t}\right)=0.0071\right)$; post-index Vit D use showed a protective effect among hospitalized postindex CRT users but a borderline detrimental effect among non-hospitalized post-index CRT users (Table 5). This interaction remained statistically significant after multiplicity correction. Among non-users of post-index CRTs, post-index Vit D use showed a protective effect, regardless of hospitalization. The $\Delta_{\mathrm{aRR}} \%$ (Vit D versus no Vit $\mathrm{D}$ ) for non-users of post-index CRTs was -8 , corresponding to a borderline significant vertical interaction compared with users of post-index corticosteroids $\left(P_{\Delta \mathrm{V}}=0.057\right.$ before MC). In contrast, among those not receiving post-index Vit D, a 50\% increased aRR (30-day mortality) was observed for hospitalized users of post-index corticosteroids (versus non-users) $(p<0.0001)$, and this represented a $\Delta_{\mathrm{aRR}} \%$ of +43 compared with non-hospitalized patients $(p=0.018$ before $\mathrm{MC})$. However, there was no evidence of either a vertical $\left(P_{\Delta \mathrm{V}}=0.81\right)$ or horizontal $\left(P_{\Delta \mathrm{H}}=0.53\right)$ interaction for the CRT comparisons. 
Table 5. Adjusted risk for non-survivors and survivors among SARS-CoV-2-positive veterans by indicated factors and comparisons.

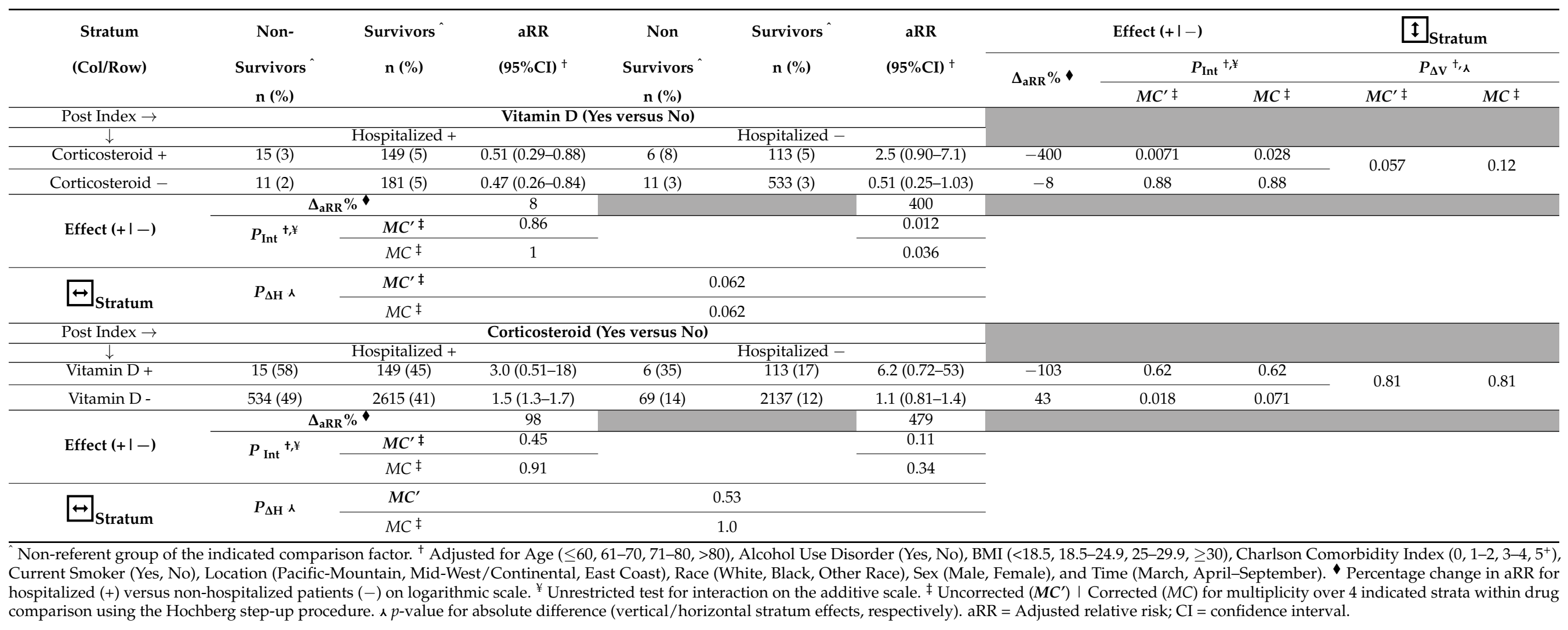




\section{Discussion}

Considerable discordance exists regarding the effectiveness of Vit D in the treatment of COVID-19, with some reports suggesting a beneficial effect $[15-17,28,29,31,41,45,53,84-106]$ and others no change $[26,27,30,32-37,44,107-109]$. The reasons for these disparate findings are likely complex and multifactorial, with varying doses, duration, and timing of Vit D administration along with patient populations and sample sizes all playing roles [110]. Differences in the criteria for defining the severity of COVID-19 may also explain, in part, the ambiguity of study results [111]. Most of the studies on this topic have been observational in design and did not account for heterogeneous comorbid conditions or the effect of CRT use. Moreover, the few randomized clinical trials published to date have been small and insufficiently powered to assure the balance of CRT use between study arms $[35,36,84,86,96]$.

Our findings suggest that post-index use of Vit D and CRT $(+I+)$ has a beneficial effect on survival among hospitalized patients with PCR-confirmed COVID-19. Considering hospitalization to be a surrogate marker for disease severity and, in many cases, the need for respiratory support, the current analysis is consistent with the RECOVERY Collaborative Group findings [73]. In the latter study, dexamethasone was associated with a harmful effect when administered to patients not receiving respiratory support, and vice versa. Accordingly, if Vit D enhances the effect of CRT, as suggested by several reports, it follows that Vit D + CRT would similarly have an increased benefit during hospitalization, when the control of inflammation versus viral replication is paramount [58-60,64-67,70,71]. The highest mortality risk in our study was noted for hospitalized patients receiving CRTs in the absence of Vit D. In contrast, the combination of Vit D and CRT significantly reduced this risk by $98 \%$ on the logarithmic scale.

As previously mentioned, CRT use in a nationally representative cohort study was associated with a two-fold reduction in endogenous Vit D levels [61]. Assuming that Vit D has a positive effect on survival, those in the CRT-only treatment group $(-I+)$, as expected and consistent with our findings, were at a survival disadvantage. Nonetheless, we cannot rule out a potentially detrimental effect of CRTs by suppressing the immune response to clear the virus.

In response to viral infection, CRTs inhibit inflammation by impeding endovascular L-selectin synthesis and through the release of granulocytes from bone marrow [112-119]. Systemic glucocorticoids have been demonstrated to improve survival when administered to COVID-19 patients who are moderately or critically ill, but their effectiveness is dependent upon timing, dose, and patient-level characteristics $[73,120]$. Perhaps equally important in identifying the best candidate for CRT therapy, as put forward by our findings, is the interaction of Vit D with CRT, especially in the context of hospitalization. Future confirmation of this hypothesis in the form of sufficiently powered randomized controlled trials is needed, although this may not be practical given the increasing rates of immunity among the population conveyed by vaccination. However, Vit D and CRT may yet be beneficial for the treatment of COVID-19 patients infected with emerging variants as the SARS-CoV-2 virus evolves over time [121].

Given the recent results of the randomized placebo-controlled trial of a one-time bolus of high-dose Vit D, which showed no improvement in hospital length of stay in COVID-19 patients [36], it is noteworthy that Vit D use by patients in our study was generally lowdose daily administration from days to weeks post-COVID-19 diagnosis. There is ample evidence that chronic, daily Vit $\mathrm{D}$ dosing is superior to bolus high-dose administration for many reasons, several of which have been summarized in recent publications [122-124]. For example, a single high dose of Vit $D$, versus daily administration, has been reported to activate the 24-hydroxylase enzyme (CYP24A1), leading to increased production of the inactive form of Vit D (i.e., $24,25(\mathrm{OH})_{2} \mathrm{D}_{3}$ ) [125]. High-dose Vit D may also suppress parathyroid hormone (PTH) through its effect on parathyroid cells [126]. PTH is an immunomodulator postulated to stimulate the phytohemagglutinin (PHA)-induced proliferation of $\mathrm{T}$ cells, important for cell-mediated immunity in the fight against infection [127-129]. In 
addition to T cells, receptors for PTH are found on neutrophils and B cells of the immune system [130]. Nonetheless, the treatment response dynamics of Vit D are complex and nonlinear, especially with respect to PTH [131].

Patients in the aforementioned clinical trial were excluded if they required invasive mechanical ventilation; most did not need noninvasive ventilation, suggesting less severe illness. Notably, CRT use has the greatest benefit among severely ill COVID-19 patients, with those being moderately ill manifesting little or no improvement [132]. Additionally, CRT use was not balanced between the study arms of this trial, thus hindering the interpretation of the reported results.

Our study was sufficiently powered to detect drug-drug interactions. Indeed, an important strength of this study is that the Veterans Health Administration (VHA) represents the largest integrated health care system in the US, with reasonably complete and up-to-date electronic database information for demographics and medication prescription details $[133,134]$. Additionally, given the longitudinal frame of the database, mortality risk on a log-binomial scale was directly estimated, thus minimizing inflated effect sizes associated with odds ratios.

A few limitations should be considered when evaluating our findings. First and foremost, this was not a randomized clinical trial. The potential for undiagnosed (untested) seropositivity owing to mild or asymptomatic cases may have biased the study results if a differential effect existed by hospitalization status. However, this bias is likely nominal given that our models were adjusted for key outcome-related variables, including the Charlson Comorbidity Index. Nonetheless, the potential remains for residual confounding, misclassification bias, collider effects, and hidden interactions among the analyzed variables as well as variables not included in our multivariable models (e.g., social determinants of health, quality of life indicators, and inability to self-isolate or manage care at home) [135].

Incomplete information on inactive users and veterans tested and treated outside the VHA health care system are other important sources of study bias unaccounted for in our analysis [136]. We also cannot rule out ascertainment bias, especially during the initial phase of the pandemic, with hospitalized patients being more likely to have high-risk conditions such as hypertension, diabetes, or renal impairment [136]. However, our analyses were adjusted for time and comorbidities. Differences in testing rates for COVID-19 have been reported in the literature, with non-White individuals generally being disproportionately represented among those infected, hospitalized, and deceased, and they similarly tend to be younger and have increased comorbid conditions [137]. In some reports, specific occupations such as health care workers were also tested more often than the general population [138]. Although the VA is generally recognized as an equal access system, study bias among ill versus healthy participants must be acknowledged if this resulted in higher or lower utilization and hospitalization rates among certain patients. Moreover, our study relied solely on SARS-CoV-2 testing to determine COVID-19 status rather than clinical adjudication.

Information on non-VA medications is based on self-reporting and may potentially have been underreported. We were unable to confirm adherence and compliance to medications among non-hospitalized patients, and this possibly introduced a variance with respect to those who were hospitalized. Owing to differences in documentation and drug nomenclature across VA clinics, determining the exact dosing and duration of Vit D and CRTs was beyond the scope of the current study. For analogous reasons, the effect of polypharmacy and the interaction with nutrients such as zinc, selenium, and vitamin $C$ on mortality was not evaluated in our analyses. We also did not consider the combination of Vit D with medications such as orlistat, statins, and thiazide diuretics, which are known to affect Vit D levels [139]. Although important in the natural history of COVID19 , changing mitigation strategies and restrictions likewise were not studied $[140,141]$. Furthermore, the potential for differential health-seeking behaviors should be noted as a possible limitation [142]. 
Protopathic bias is another factor to consider when evaluating our findings. Levels of Vit D have been reported to precipitously drop during the initial, acute inflammatory phase of critical illness [109]. Conceivably, severe COVID-19 may manifest as lowered Vit D levels, in turn necessitating the need for this vitamin among hospitalized patients. However, this potential reverse causality effect would not explain the interaction with CRTs or the multinomial results observed in our study. Indeed, the opposite appears to be the case in that the mortality risk among hospitalized patients receiving both Vit D and CRTs was statistically lower than that for patients using CRTs in the absence of Vit D. While hospitalization status was considered a surrogate marker of disease severity in our analysis, we recognize that different patients might have presented to the hospital with varying states of acute illness [109]. We also acknowledge that the response to Vit D in patients with already high levels at the time of hospital admission may be more beneficial than efforts aimed at increasing levels within a brief window with treatment [105]. In future analyses, we will aim to delineate individual dose levels by model covariates and outcome variables.

Our sample, while reflective of the VHA population, consisted mainly of older males, with only $11 \%$ being female $[133,134,140,141]$. Patients treated within the VHA tend to be at higher risk with more medically complex conditions than the US population [143]. Veterans, especially those with obesity, diabetes, cardiac diseases, and a history of military exposures, may be more susceptible to COVID-19-induced inflammatory conditions and poor recovery from the disease owing to decreased reserve and pre-existing endothelial dysfunction (these conditions, which have been linked to Vit D deficiency, suggest a potential benefit of Vit D to augment host response to COVID-19) [144-146]. In Hawaii, for example, where sunlight is abundant, veterans newly admitted to a nursing home were observed to have a very high prevalence of Vit D deficiency [147], which was presumably higher than that for non-veterans. Hence, we cannot guarantee that our results are generalizable to other health care systems, even after carefully adjusting for key outcome-related confounders. Lastly, our study did not consider polymorphisms of Vit D metabolism and Vit D binding protein when analyzing the interaction of Vit D and CRT use [148,149].

Independent of COVID-19, lower levels of 25-hydroxyvitamin D (25D) on day 1 of intensive care unit (ICU) admission have been associated with decreased production of cathelicidin antimicrobial protein-18 (hCAP-18) and greater mortality risk at three months [132]. Patients in the ICU are, in general, at risk of having lower levels of 25hydroxyvitamin D (25D) and suboptimal cellular oxygenation for various reasons (e.g., fluid resuscitation, renal failure, cardiac/respiratory failure, and gastrointestinal bleeding) [150]. When administered in this setting, Vit D replacement therapy may, in theory, reduce mortality by increasing hemoglobulin levels, decreasing hepcidin concentrations, and facilitating oxygenation at the cellular level [105]. Thus, aspects of Vit D use noted in the current paper may also apply overall to hospitalized patients with severe illness, warranting a study of Vit D in this broader population while considering a possible interaction with CRT use in the study design.

The use of Vit D in excess amounts ( $>50,000$ IU per day) is toxic and may lead to hypercalcemia and hyperphosphatemia $[139,150]$. Accordingly, patients are advised to avoid high doses of Vit D for the prevention or treatment of COVID-19 unless prescribed by a licensed health care provider.

\section{Conclusions}

In accordance with our hypothesis and the results from this large observational study, there appears to be an interaction between post-index use of Vit D and CRT with respect to 30-day mortality among hospitalized versus non-hospitalized patients testing positive for SARS-CoV-2. Future independent analyses are needed to validate this effect and the importance to both clinical practice and our understanding of COVID-19 pathophysiology.

Author Contributions: Conceptualization, J.T.E., A.S. and E.J.A.; data curation, T.S.R., A.D.T. and J.T.E.; formal analysis, J.T.E., T.S.R. and A.D.T.; funding acquisition, A.S.; methodology, J.T.E.; project administration, A.S., A.M.P. and J.U.; supervision, A.S. and J.T.E.; validation, A.D.T.; visualization, 
E.J.A.; writing—original draft, J.T.E. and A.S.; writing—review and editing, J.T.E., E.J.A., C.J., T.S.R., A.D.T., A.M.P., J.U., C.D.W., Y.M.C. and A.S. The corresponding author attests that all listed authors meet the authorship criteria and that no others meeting the criteria have been omitted. The corresponding author further affirms that the manuscript is an honest, accurate, and transparent account of the study. All authors have read and agreed to the published version of the manuscript.

Funding: This work was supported by the Veterans Affairs (VA) Clinical Science Research and Development COVID Rapid Response program (Funding Number: FY2021 ORD-COVID-19-8900-02) as well as resources of the Durham VA Medical Center and Durham Cooperative Studies Program Epidemiology Center.

Institutional Review Board Statement: The study was approved by the Institutional Review Board and the Research and Development Committee of Durham VA Medical Center (ID \#02297 was approved on 27 May 2020).

Informed Consent Statement: The Institutional Review Board at the Durham VA Medical Center determined that this study meets exempt human subjects research criteria Category 4 and an informed consent form is not applicable.

Data Availability Statement: These analyses were performed using raw data that are available only within the US Department of Veterans Affairs firewall in a secure research environment, the VA Informatics and Computing Infrastructure. To comply with VA privacy and data security policies and regulatory constraints, only aggregate summary statistics and results of our analyses are permitted to be removed from the data warehouse for publication. The authors have provided detailed results of the analyses in the paper. These restrictions are in place to maintain patient privacy and confidentiality.

Acknowledgments: This study was made possible using data from the VA COVID-19 Shared Data Resource and the resources and facilities of the Department of Veterans Affairs Informatics and Computing Infrastructure, VA HSR RES 13-457. We acknowledge the use of the Observational Medical Outcomes Partnership Common Core Library, an SQL library developed in The Center for Improving the Public's Health through Informatics (CIPHI) in the Department of Biomedical Informatics (DBMI) at Vanderbilt Health (VUMC), graciously provided by Michael E. Matheny, Chad Dorn, and Ruth M Reeves. The authors wish to thank Dawn Provenzale (in memoriam; VA Cooperative Studies Program Epidemiology Center-Durham; Director, GI Outcomes Research, Duke University; Professor of Medicine, Duke University Medical Center) for her thoughtful input and support. We also acknowledge Theodore Berkowitz (Statistician) for his useful comments and suggested edits to the manuscript. The views expressed in this article are those of the authors and do not necessarily reflect the position or policy of the Department of Veterans Affairs.

Conflicts of Interest: The authors declare no conflict of interest.

\section{References}

1. Korf, H.; Decallonne, B.; Mathieu, C. Vitamin D for infections. Curr. Opin. Endocrinol. Diabetes Obes. 2014, 21, 431-436. [CrossRef] [PubMed]

2. Yin, K.; Agrawal, D.K. Vitamin D and inflammatory diseases. J. Inflamm. Res. 2014, 7, 69-87. [CrossRef]

3. Ismailova, A.; White, J.H. Vitamin D, infections and immunity. Rev. Endocr. Metab. Disord. 2021, 1-13. [CrossRef] [PubMed]

4. Holick, M.F. Vitamin D Deficiency. N. Engl. J. Med. 2007, 357, 266-281. [CrossRef] [PubMed]

5. Reijven, P.L.M.; Soeters, P.B. Vitamin D: A magic bullet or a myth? Clin. Nutr. 2020, 39, 2663-2674. [CrossRef] [PubMed]

6. Brenner, H. Vitamin D Supplementation to Prevent COVID-19 Infections and Deaths-Accumulating Evidence from Epidemiological and Intervention Studies Calls for Immediate Action. Nutrients 2021, 13, 411. [CrossRef] [PubMed]

7. Raisi-Estabragh, Z.; Martineau, A.R.; Curtis, E.M.; Moon, R.J.; Darling, A.; Lanham-New, S.; Ward, K.A.; Cooper, C.; Munroe, P.B.; Petersen, S.E.; et al. Vitamin D and coronavirus disease 2019 (COVID-19): Rapid evidence review. Aging Clin. Exp. Res. 2021, 33, 2031-2041. [CrossRef]

8. Bilezikian, J.P.; Bikle, D.; Hewison, M.; Lazaretti-Castro, M.; Formenti, A.M.; Gupta, A.; Madhavan, M.V.; Nair, N.; Babalyan, V.; Hutchings, N.; et al. Mechanisma in endocrinology: Vitamin D and COVID-19. Eur. J. Endocrinol. 2020, 183, R133-R147. [CrossRef]

9. Arthur, P. Vitamine D et COVID-19. Bull. Acad. Natl. Med. 2020, 204, 721-722.

10. Vaughan, M.; Trott, M.; Sapkota, R.; Premi, G.; Roberts, J.; Ubhi, J.; Smith, L.; Pardhan, S. Changes in 25-hydroxyvitamin D levels post-vitamin D supplementation in people of Black and Asian ethnicities and its implications during COVID-19 pandemic: A systematic review. J. Hum. Nutr. Diet. 2021, 12949. [CrossRef] [PubMed] 
11. Iacobucci, G. COVID-19: NHS bosses told to assess risk to ethnic minority staff who may be at greater risk. BMJ 2020, 369, m1820. [CrossRef]

12. Turrubiates-Hernández, F.J.; Sánchez-Zuno, G.A.; González-Estevez, G.; Hernández-Bello, J.; Macedo-Ojeda, G.; Muñoz-Valle, J.F. Potential immunomodulatory effects of vitamin D in the prevention of severe coronavirus disease 2019: An ally for Latin America (Review). Int. J. Mol. Med. 2021, 47, 1. [CrossRef]

13. Kishore, J.; Grimes, D.S.; Anderson, D.C.; Bharti, O.K.; Joseph, B.; Ghai, G.; Sahoo, M. Recommendations for High Vitamin D Supplementation to help Fight the COVID-19 Pandemic and its Inclusion in National COVID-19 Management Guidelines. Epidem. Int. 2021, 6, 6-9.

14. Munshi, R.; Hussein, M.H.; Toraih, E.A.; Elshazli, R.M.; Jardak, C.; Sultana, N.; Youssef, M.R.; Omar, M.; Attia, A.S.; Fawzy, M.S.; et al. Vitamin D insufficiency as a potential culprit in critical COVID-19 patients. J. Med. Virol. 2021, 93, 733-740. [CrossRef] [PubMed]

15. Luo, X.; Liao, Q.; Shen, Y.; Li, H.; Cheng, L. Vitamin D Deficiency Is Associated with COVID-19 Incidence and Disease Severity in Chinese People. J. Nutr. 2021, 151, 98-103. [CrossRef]

16. Tehrani, S.; Khabiri, N.; Moradi, H.; Mosavat, M.S.; Khabiri, S.S. Evaluation of vitamin D levels in COVID-19 patients referred to Labafinejad hospital in Tehran and its relationship with disease severity and mortality. Clin. Nutr. ESPEN 2021, $42,313-317$. [CrossRef]

17. Reis, B.Z.; Fernandes, A.L.; Sales, L.P.; Santos, M.D.; Dos Santos, C.C.; Pinto, A.J.; Goessler, K.F.; Franco, A.S.; Duran, C.S.C.; Silva, C.B.R.; et al. Influence of vitamin D status on hospital length of stay and prognosis in hospitalized patients with moderate to severe COVID-19: A multicenter prospective cohort study. Am. J. Clin. Nutr. 2021, 114, 598-604. [CrossRef]

18. Borsche, L.; Glauner, B.; von Mendel, J. COVID-19 mortality risk correlates inversely with vitamin D3 status, and a mortality rate close to zero could theoretically be achieved at $50 \mathrm{ng} / \mathrm{ml} 25(\mathrm{OH}) \mathrm{D} 3$ : Results of a systematic review and meta-analysis. medRxiv 2021, 13, 3596. [CrossRef]

19. Benskin, L.L. The influence of vitamin D on COVID-19 outcomes. In COVID-19 and Nutraceuticals: A Guidebook; Bohr Publishers and New Century Health Publishers: Tamil Nadu, India, 2021.

20. Dramé, M.; Cofais, C.; Hentzien, M.; Proye, E.; Coulibaly, P.S.; Demoustier-Tampère, D.; Destailleur, M.H.; Lotin, M.; Cantagrit, E.; Cebille, A.; et al. Relation between Vitamin D and COVID-19 in Aged People: A Systematic Review. Nutrients 2021, 13, 1339. [CrossRef]

21. Pal, R.; Banerjee, M.; Bhadada, S.K.; Shetty, A.J.; Singh, B.; Vyas, A. Vitamin D supplementation and clinical outcomes in COVID-19: A systematic review and meta-analysis. J. Endocrinol. Investig. 2021, 1-16. [CrossRef]

22. Hariyanto, T.I.; Intan, D.; Hananto, J.E.; Harapan, H.; Kurniawan, A. Vitamin D supplementation and Covid-19 outcomes: A systematic review, meta-analysis and meta-regression. Rev. Med. Virol. 2021, 27, e2269. [CrossRef]

23. Han, J.E.; Jones, J.L.; Tangpricha, V.; Brown, M.A.; Brown, L.A.S.; Hao, L.; Hebbar, G.; Lee, M.J.; Liu, S.; Ziegler, T.R.; et al. High Dose Vitamin D Administration in Ventilated Intensive Care Unit Patients: A Pilot Double Blind Randomized Controlled Trial. J. Clin. Transl. Endocrinol. 2016, 4, 59-65. [CrossRef] [PubMed]

24. Da Rocha, A.P.; Atallah, A.N.; Aldrighi, J.M.; Pires, A.L.R.; Dos Santos Puga, M.E.; Pinto, A. Insufficient evidence for vitamin D use in COVID-19: A rapid systematic review. Int. J. Clin. Pract. 2021, 75, e14649. [CrossRef]

25. Boaz, M. Vitamin D and COVID-19: Partial Evidence. BCHD 2021, 4, 40-44. [CrossRef]

26. Cereda, E.; Bogliolo, L.; Klersy, C.; Lobascio, F.; Masi, S.; Crotti, S.; De Stefano, L.; Bruno, R.; Corsico, A.G.; Di Sabatino, A.; et al. Vitamin D 25OH deficiency in COVID-19 patients admitted to a tertiary referral hospital. Clin. Nutr. 2021, 40, $2469-2472$. [CrossRef]

27. Cereda, E.; Bogliolo, L.; Lobascio, F.; Barichella, M.; Zecchinelli, A.L.; Pezzoli, G.; Caccialanza, R. Vitamin D supplementation and outcomes in coronavirus disease 2019 (COVID-19) patients from the outbreak area of Lombardy, Italy. Nutrition 2021, 82, 111055. [CrossRef] [PubMed]

28. Campi, I.; Gennari, L.; Merlotti, D.; Mingiano, C.; Frosali, A.; Giovanelli, L.; Torlasco, C.; Pengo, M.F.; Heilbron, F.; Soranna, D.; et al. Vitamin D and COVID-19 severity and related mortality: A prospective study in Italy. BMC Infect. Dis. 2021, 21, 566. [CrossRef]

29. Mariani, J.; Giménez, V.M.M.; Bergam, I.; Tajer, C.; Antonietti, L.; Inserra, F.; Ferder, L.; Manucha, W. Association Between Vitamin D Deficiency and COVID-19 Incidence, Complications, and Mortality in 46 Countries: An Ecological Study. Health Secur. 2021, 19, 302-308. [CrossRef]

30. Baktash, V.; Hosack, T.; Patel, N.; Shah, S.; Kandiah, P.; Van den Abbeele, K.; Mandal, A.K.J.; Missouris, C.G. Vitamin D status and outcomes for hospitalised older patients with COVID-19. Postgrad. Med. J. 2021, 97, 442-447. [CrossRef]

31. Radujkovic, A.; Hippchen, T.; Tiwari-Heckler, S.; Dreher, S.; Boxberger, M.; Merle, U. Vitamin D Deficiency and Outcome of COVID-19 Patients. Nutrients 2020, 12, 2757. [CrossRef] [PubMed]

32. Bianconi, V.; Mannarino, M.R.; Figorilli, F.; Cosentini, E.; Batori, G.; Marini, E.; Lombardini, R.; Gargaro, M.; Fallarino, F.; Scarponi, A.M.; et al. Prevalence of vitamin D deficiency and its prognostic impact on patients hospitalized with COVID-19. Nutrition 2021, 91-92, 111408. [CrossRef]

33. Pecina, J.L.; Merry, S.P.; Park, J.G.; Thacher, T.D. Vitamin D Status and Severe COVID-19 Disease Outcomes in Hospitalized Patients. J. Prim. Care Community Health 2021, 12, 21501327211041206. [CrossRef] 
34. Butler-Laporte, G.; Nakanishi, T.; Mooser, V.; Morrison, D.R.; Abdullah, T.; Adeleye, O.; Mamlouk, N.; Kimchi, N.; Afrasiabi, Z.; Rezk, N.; et al. Vitamin D and COVID-19 susceptibility and severity in the COVID-19 Host Genetics Initiative: A Mendelian randomization study. PLoS Med. 2021, 18, e1003605. [CrossRef] [PubMed]

35. Soliman, A.R.; Abdelaziz, T.S.; Fathy, A. Impact of Vitamin D Therapy on the Progress COVID-19: Six Weeks Follow-Up Study of Vitamin D Deficient Elderly Diabetes Patients. Proc. Singap. Health 2021, 20101058211041405. [CrossRef]

36. Murai, I.H.; Fernandes, A.L.; Sales, L.P.; Pinto, A.J.; Goessler, K.F.; Duran, C.S.C.; Silva, C.B.R.; Franco, A.S.; Macedo, M.B.; Dalmolin, H.H.H.; et al. Effect of a Single High Dose of Vitamin D3 on Hospital Length of Stay in Patients with Moderate to Severe COVID-19: A Randomized Clinical Trial. JAMA 2021, 325, 1053-1060. [CrossRef]

37. Güven, M.; Gültekin, H. The effect of high-dose parenteral vitamin D(3) on COVID-19-related inhospital mortality in critical COVID-19 patients during intensive care unit admission: An observational cohort study. Eur. J. Clin. Nutr. 2021, 75, 1383-1388. [CrossRef]

38. Bassatne, A.; Basbous, M.; Chakhtoura, M.; El Zein, O.; Rahme, M.; El-Hajj Fuleihan, G. The link between COVID-19 and VItamin D (VIVID): A systematic review and meta-analysis. Metabolism 2021, 119, 154753. [CrossRef] [PubMed]

39. Kazemi, A.; Mohammadi, V.; Aghababaee, S.K.; Golzarand, M.; Clark, C.C.T.; Babajafari, S. Association of Vitamin D Status with SARS-CoV-2 Infection or COVID-19 Severity: A Systematic Review and Meta-analysis. Adv. Nutr. 2021, 12, 1636-1658. [CrossRef] [PubMed]

40. Santaolalla, A.; Beckmann, K.; Kibaru, J.; Josephs, D.; Van Hemelrijck, M.; Irshad, S. Association Between Vitamin D and Novel SARS-CoV-2 Respiratory Dysfunction-A Scoping Review of Current Evidence and Its Implication for COVID-19 Pandemic. Front. Physiol. 2020, 11, 564387. [CrossRef]

41. Sánchez-Zuno, G.A.; González-Estevez, G.; Matuz-Flores, M.G.; Macedo-Ojeda, G.; Hernández-Bello, J.; Mora-Mora, J.C.; PérezGuerrero, E.E.; García-Chagollán, M.; Vega-Magaña, N.; Turrubiates-Hernández, F.J.; et al. Vitamin D Levels in COVID-19 Outpatients from Western Mexico: Clinical Correlation and Effect of Its Supplementation. J. Clin. Med. 2021, 10, 2378. [CrossRef]

42. Gibson-Moore, H. Vitamin D: What's new a year on from the COVID-19 outbreak? Nutr. Bull. 2021, 46, 195-205. [CrossRef]

43. Craft, J.F.; Travassos, M.A.; Foppiano Palacios, C.; Openshaw, J.J. Inadequate Minority Representation within SARS-CoV-2 Vaccine Trials. Am. J. Trop. Med. Hyg. 2021, 104, 32-34. [CrossRef] [PubMed]

44. Szeto, B.; Zucker, J.E.; LaSota, E.D.; Rubin, M.R.; Walker, M.D.; Yin, M.T.; Cohen, A. Vitamin D Status and COVID-19 Clinical Outcomes in Hospitalized Patients. Endocr. Res. 2021, 46, 66-73. [CrossRef] [PubMed]

45. Carpagnano, G.E.; Di Lecce, V.; Quaranta, V.N.; Zito, A.; Buonamico, E.; Capozza, E.; Palumbo, A.; Di Gioia, G.; Valerio, V.N.; Resta, O. Vitamin D deficiency as a predictor of poor prognosis in patients with acute respiratory failure due to COVID-19. J. Endocrinol. Investig. 2021, 44, 765-771. [CrossRef]

46. Arvinte, C.; Singh, M.; Marik, P.E. Serum Levels of Vitamin C and Vitamin D in a Cohort of Critically Ill COVID-19 Patients of a North American Community Hospital Intensive Care Unit in May 2020: A Pilot Study. Med. Drug Discov. 2020, $8,100064$. [CrossRef]

47. Abrishami, A.; Dalili, N.; Mohammadi Torbati, P.; Asgari, R.; Arab-Ahmadi, M.; Behnam, B.; Sanei-Taheri, M. Possible association of vitamin D status with lung involvement and outcome in patients with COVID-19: A retrospective study. Eur. J. Nutr. 2021, 60, 2249-2257. [CrossRef]

48. Pizzini, A.; Aichner, M.; Sahanic, S.; Böhm, A.; Egger, A.; Hoermann, G.; Kurz, K.; Widmann, G.; Bellmann-Weiler, R.; Weiss, G.; et al. Impact of Vitamin D Deficiency on COVID-19-A Prospective Analysis from the CovILD Registry. Nutrients 2020, 12, 2775. [CrossRef]

49. Kerget, B.; Kerget, F.; Kızıltunç, A.; Koçak, A.O.; Araz, Ö.; Yılmazel Uçar, E.; Akgün, M. Evaluation of the relationship of serum vitamin D levels in COVID-19 patients with clinical course and prognosis. Tuberk. Torak 2020, 68, 227-235. [CrossRef]

50. Karonova, T.L.; Andreeva, A.T.; Vashukova, M.A. Serum 25 (OH) D level in COVID-19 patients. J. Infectol. 2020, $12,21-27$. [CrossRef]

51. Faul, J.L.; Kerley, C.P.; Love, B.; O’Neill, E.; Cody, C.; Tormey, W.; Hutchinson, K.; Cormican, L.J.; Burke, C.M. Vitamin D Deficiency and ARDS after SARS-CoV-2 Infection. Ir. Med. J. 2020, 113, 84.

52. De Smet, D.; De Smet, K.; Herroelen, P.; Gryspeerdt, S.; Martens, G.A. Serum 25(OH)D Level on Hospital Admission Associated with COVID-19 Stage and Mortality. Am. J. Clin. Pathol. 2021, 155, 381-388. [CrossRef] [PubMed]

53. Ye, K.; Tang, F.; Liao, X.; Shaw, B.A.; Deng, M.; Huang, G.; Qin, Z.; Peng, X.; Xiao, H.; Chen, C.; et al. Does Serum Vitamin D Level Affect COVID-19 Infection and Its Severity? A Case-Control Study. J. Am. Coll. Nutr. 2020, 40, 724-731. [CrossRef]

54. Mardani, R.; Alamdary, A.; Mousavi Nasab, S.D.; Gholami, R.; Ahmadi, N.; Gholami, A. Association of vitamin D with the modulation of the disease severity in COVID-19. Virus Res. 2020, 289, 198148. [CrossRef] [PubMed]

55. Mandal, A.K.; Wenban, C.; Heer, R.S.; Baktash, V.; Missouris, C.G. Does Vitamin D have a role to play in COVID-19 in the dexamethasone era? Diabetes Metab. Syndr. Clin. Res. Rev. 2021, 15, 102237. [CrossRef] [PubMed]

56. Wenban, C.; Heer, R.S.; Baktash, V.; Kandiah, P.; Katsanouli, T.; Pandey, A.; Goindoo, R.; Ajaz, A.; Van den Abbeele, K.; Mandal, A.K.J.; et al. Dexamethasone treatment may mitigate adverse effects of vitamin D deficiency in hospitalized COVID-19 patients. J. Med. Virol. 2021, 93, 6605-6610. [CrossRef] [PubMed]

57. Hahn, D.L. Glucocorticosteroids are potential confounders in studies of vitamin D and asthma. Am. J. Respir. Crit. Care Med. 2012, 185, 1245; author reply 1245-1246. [CrossRef] [PubMed] 
58. Mehta, A.A.; Agrawal, A.D.; Appanna, V.; Chaudagar, K.K. Vitamin D improves corticosteroid efficacy and attenuates its side-effects in an animal model of asthma. Can. J. Physiol. Pharmacol. 2015, 93, 53-61. [CrossRef]

59. Agrawal, A.D. Evaluation of Corticosteroids-Vitamin D Combination in Asthma. PhD Thesis, Gujarat Technological University, Ahmedabad, India, 2016.

60. Dhawan, P.; Christakos, S. Novel regulation of 25-hydroxyvitamin D3 24-hydroxylase (24(OH)ase) transcription by glucocorticoids:Ccooperative effects of the glucocorticoid receptor, C/EBP beta, and the Vitamin D receptor in $24(\mathrm{OH})$ ase transcription. J. Cell. Biochem. 2010, 110, 1314-1323. [CrossRef] [PubMed]

61. Skversky, A.L.; Kumar, J.; Abramowitz, M.K.; Kaskel, F.J.; Melamed, M.L. Association of glucocorticoid use and low 25hydroxyvitamin D levels: Results from the National Health and Nutrition Examination Survey (NHANES): 2001-2006. J. Clin. Endocrinol. Metab. 2011, 96, 3838-3845. [CrossRef]

62. Davidson, Z.E.; Walker, K.Z.; Truby, H. Do glucocorticosteroids alter vitamin D status? A systematic review with meta-analyses of observational studies. J. Clin. Endocrinol. Metab. 2012, 97, 738-744. [CrossRef] [PubMed]

63. Zoorob, R.J.; Cender, D. A different look at corticosteroids. Am. Fam. Physician 1998, 58, 443-450.

64. Hidalgo, A.A.; Deeb, K.K.; Pike, J.W.; Johnson, C.S.; Trump, D.L. Dexamethasone enhances 1alpha,25-dihydroxyvitamin D3 effects by increasing vitamin D receptor transcription. J. Biol. Chem. 2011, 286, 36228-36237. [CrossRef]

65. Zella, L.A.; Meyer, M.B.; Nerenz, R.D.; Lee, S.M.; Martowicz, M.L.; Pike, J.W. Multifunctional enhancers regulate mouse and human vitamin D receptor gene transcription. Mol. Endocrinol. 2010, 24, 128-147. [CrossRef]

66. Kurahashi, I.; Matsunuma, A.; Kawane, T.; Abe, M.; Horiuchi, N. Dexamethasone enhances vitamin D-24-hydroxylase expression in osteoblastic (UMR-106) and renal (LLC-PK1) cells treated with 1alpha,25-dihydroxyvitamin D3. Endocrine 2002, 17, 109-118. [CrossRef]

67. Xystrakis, E.; Kusumakar, S.; Boswell, S.; Peek, E.; Urry, Z.; Richards, D.F.; Adikibi, T.; Pridgeon, C.; Dallman, M.; Loke, T.K.; et al. Reversing the defective induction of IL-10-secreting regulatory T cells in glucocorticoid-resistant asthma patients. J. Clin. Investig. 2006, 116, 146-155. [CrossRef]

68. Searing, D.A.; Zhang, Y.; Murphy, J.R.; Hauk, P.J.; Goleva, E.; Leung, D.Y. Decreased serum vitamin D levels in children with asthma are associated with increased corticosteroid use. J. Allergy Clin. Immunol. 2010, 125, 995-1000. [CrossRef]

69. Zhang, Y.G.; Wu, S.; Sun, J. Vitamin D, Vitamin D Receptor, and Tissue Barriers. Tissue Barriers 2013, 1, e23118. [CrossRef]

70. Ferreira, G.B.; Kleijwegt, F.S.; Waelkens, E.; Lage, K.; Nikolic, T.; Hansen, D.A.; Workman, C.T.; Roep, B.O.; Overbergh, L.; Mathieu, C. Differential protein pathways in 1,25-dihydroxyvitamin d(3) and dexamethasone modulated tolerogenic human dendritic cells. J. Proteome Res. 2012, 11, 941-971. [CrossRef] [PubMed]

71. Penna, G.; Amuchastegui, S.; Giarratana, N.; Daniel, K.C.; Vulcano, M.; Sozzani, S.; Adorini, L. 1,25-Dihydroxyvitamin D3 selectively modulates tolerogenic properties in myeloid but not plasmacytoid dendritic cells. J. Immunol. 2007, 178, 145-153. [CrossRef]

72. Garg, S.; Patel, K.; Pham, H.; Whitaker, M.; O’Halloran, A.; Milucky, J.; Anglin, O.; Kirley, P.D.; Reingold, A.; Kawasaki, B.; et al. Clinical Trends Among U.S. Adults Hospitalized With COVID-19, March to December 2020: A Cross-Sectional Study. Ann. Intern. Med. 2021, 174, 1409-1419. [CrossRef]

73. Horby, P.; Lim, W.S.; Emberson, J.R.; Mafham, M.; Bell, J.L.; Linsell, L.; Staplin, N.; Brightling, C.; Ustianowski, A.; Elmahi, E.; et al. Dexamethasone in Hospitalized Patients with COVID-19. N. Engl. J. Med. 2021, 384, 693-704. [CrossRef]

74. Suzuki, A.; Efird, J.T.; Redding, T.S.t.; Thompson, A.D., Jr.; Press, A.M.; Williams, C.D.; Hostler, C.J.; Hunt, C.M. COVID-19Associated Mortality in US Veterans with and without SARS-CoV-2 Infection. Int. J. Environ. Res. Public Health 2021, $18,8486$. [CrossRef]

75. DuVall, S.; Scehnet, J. VA Informatics and Computing Infrastructure: Introduction to the VA COVID-19 Shared Data Resource and Its Use for Research NW Washington DC 204202020. Available online: https: / www.hsrd.research.va.gov/cyberseminars / catalog-upcoming-session.cfm?UID=3810 (accessed on 29 November 2021).

76. Chapman, A.; Peterson, K.; Turano, A.; Box, T.; Wallace, K.; Jones, M. A Natural Language Processing System for National COVID19 Surveillance in the US Department of Veterans Affairs. Available online: https://openreview.net/forum?id=ZQ_HvBxcdCv (accessed on 4 December 2020).

77. Basheer, M.; Saad, E.; Shlezinger, D.; Assy, N. Convalescent Plasma Reduces Mortality and Decreases Hospitalization Stay in Patients with Moderate COVID-19 Pneumonia. Metabolites 2021, 11, 761. [CrossRef]

78. Breslow, N.E.; Day, N.E. The Analysis of Case-control Studies. In Statistical Methods in Cancer Research; IARC Scientific Publications No. 32; International Agency for Research on Cancer: Lyon, France, 1980; Volume 1.

79. Bland, M. Introduction to Medical Statistics; Oxford University Press: Oxford, UK, 2015; p. 464.

80. Efird, J.T. Goldilocks Rounding: Achieving Balance between Accuracy and Parsimony in the Reporting of Relative Effect Estimates. Cancer Inform. 2021, 20, 1176935120985132. [CrossRef]

81. Benjamini, Y.; Yekutieli, D. False Discovery Rate-Adjusted Multiple Confidence Intervals for Selected Parameters. J. Am. Stat. Assoc. 2005, 100, 71-81. [CrossRef]

82. Hochberg, Y. A sharper Bonferroni procedure for multiple tests of significance. Biometrika 1988, 75, 800-802. [CrossRef]

83. Sundberg, R. An iterative method for solution of the likelihood equations for incomplete data from exponential families. Commun. Stat.-Simul. Comput. 1976, 5, 55-64. [CrossRef] 
84. Maghbooli, Z.; Sahraian, M.A.; Jamalimoghadamsiahkali, S.; Asadi, A.; Zarei, A.; Zendehdel, A.; Varzandi, T.; Mohammadnabi, S.; Alijani, N.; Karimi, M.; et al. Treatment with 25-Hydroxyvitamin D(3) (Calcifediol) Is Associated with a Reduction in the Blood Neutrophil-to-Lymphocyte Ratio Marker of Disease Severity in Hospitalized Patients with COVID-19: A Pilot Multicenter, Randomized, Placebo-Controlled, Double-Blinded Clinical Trial. Endocr. Pract. 2021, 27, 1242-1251. [CrossRef]

85. Ohaegbulam, K.C.; Swalih, M.; Patel, P.; Smith, M.A.; Perrin, R. Vitamin D Supplementation in COVID-19 Patients: A Clinical Case Series. Am. J. Ther. 2020, 27, e485-e490. [CrossRef]

86. Lakkireddy, M.; Gadiga, S.G.; Malathi, R.D.; Karra, M.L.; Raju, I.; Ragini; Chinapaka, S.; Baba, K.; Kandakatla, M. Impact of daily high dose oral vitamin D therapy on the inflammatory markers in patients with COVID 19 disease. Sci. Rep. 2021, $11,10641$. [CrossRef]

87. Annweiler, C.; Hanotte, B.; Grandin de l’Eprevier, C.; Sabatier, J.M.; Lafaie, L.; Célarier, T. Vitamin D and survival in COVID-19 patients: A quasi-experimental study. J. Steroid Biochem. Mol. Biol. 2020, 204, 105771. [CrossRef]

88. Annweiler, G.; Corvaisier, M.; Gautier, J.; Dubée, V.; Legrand, E.; Sacco, G.; Annweiler, C. Vitamin D Supplementation Associated to Better Survival in Hospitalized Frail Elderly COVID-19 Patients: The GERIA-COVID Quasi-Experimental Study. Nutrients 2020, 12, 3377. [CrossRef]

89. Ling, S.F.; Broad, E.; Murphy, R.; Pappachan, J.M.; Pardesi-Newton, S.; Kong, M.F.; Jude, E.B. High-Dose Cholecalciferol Booster Therapy is Associated with a Reduced Risk of Mortality in Patients with COVID-19: A Cross-Sectional Multi-Centre Observational Study. Nutrients 2020, 12, 3799. [CrossRef] [PubMed]

90. Giannini, S.; Passeri, G.; Tripepi, G.; Sella, S.; Fusaro, M.; Arcidiacono, G.; Torres, M.O.; Michielin, A.; Prandini, T.; Baffa, V.; et al. Effectiveness of In-Hospital Cholecalciferol Use on Clinical Outcomes in Comorbid COVID-19 Patients: A Hypothesis-Generating Study. Nutrients 2021, 13, 219. [CrossRef]

91. Entrenas Castillo, M.; Entrenas Costa, L.M.; Vaquero Barrios, J.M.; Alcalá Díaz, J.F.; López Miranda, J.; Bouillon, R.; Quesada Gomez, J.M. Effect of calcifediol treatment and best available therapy versus best available therapy on intensive care unit admission and mortality among patients hospitalized for COVID-19: A pilot randomized clinical study. J. Steroid Biochem. Mol. Biol. 2020, 203, 105751. [CrossRef] [PubMed]

92. Alcala-Diaz, J.F.; Limia-Perez, L.; Gomez-Huelgas, R.; Martin-Escalante, M.D.; Cortes-Rodriguez, B.; Zambrana-Garcia, J.L.; Entrenas-Castillo, M.; Perez-Caballero, A.I.; López-Carmona, M.D.; Garcia-Alegria, J.; et al. Calcifediol Treatment and Hospital Mortality Due to COVID-19: A Cohort Study. Nutrients 2021, 13, 1760. [CrossRef]

93. Cangiano, B.; Fatti, L.M.; Danesi, L.; Gazzano, G.; Croci, M.; Vitale, G.; Gilardini, L.; Bonadonna, S.; Chiodini, I.; Caparello, C.F.; et al. Mortality in an Italian nursing home during COVID-19 pandemic: Correlation with gender, age, ADL, vitamin D supplementation, and limitations of the diagnostic tests. Aging 2020, 12, 24522-24534. [CrossRef]

94. Vasheghani, M.; Jannati, N.; Baghaei, P.; Rezaei, M.; Aliyari, R.; Marjani, M. The relationship between serum 25-hydroxyvitamin D levels and the severity of COVID-19 disease and its mortality. Sci. Rep. 2021, 11, 17594. [CrossRef]

95. Tan, C.W.; Ho, L.P.; Kalimuddin, S.; Cherng, B.P.Z.; Teh, Y.E.; Thien, S.Y.; Wong, H.M.; Tern, P.J.W.; Chandran, M.; Chay, J.W.M.; et al. Cohort study to evaluate the effect of vitamin $\mathrm{D}$, magnesium, and vitamin $\mathrm{B}(12)$ in combination on progression to severe outcomes in older patients with coronavirus (COVID-19). Nutrition 2020, 79-80, 111017. [CrossRef]

96. Rastogi, A.; Bhansali, A.; Khare, N.; Suri, V.; Yaddanapudi, N.; Sachdeva, N.; Puri, G.D.; Malhotra, P. Short term, high-dose vitamin D supplementation for COVID-19 disease: A randomised, placebo-controlled, study (SHADE study). Postgrad. Med. J. 2020, 1-4. [CrossRef]

97. Jungreis, I.; Kellis, M. Mathematical analysis of Córdoba calcifediol trial suggests strong role for Vitamin D in reducing ICU admissions of hospitalized COVID-19 patients. medRxiv 2020. [CrossRef]

98. Alguwaihes, A.M.; Sabico, S.; Hasanato, R.; Al-Sofiani, M.E.; Megdad, M.; Albader, S.S.; Alsari, M.H.; Alelayan, A.; Alyusuf, E.Y.; Alzahrani, S.H.; et al. Severe vitamin D deficiency is not related to SARS-CoV-2 infection but may increase mortality risk in hospitalized adults: A retrospective case-control study in an Arab Gulf country. Aging Clin. Exp. Res. 2021, 33, 1415-1422. [CrossRef]

99. Jain, A.; Chaurasia, R.; Sengar, N.S.; Singh, M.; Mahor, S.; Narain, S. Analysis of vitamin D level among asymptomatic and critically ill COVID-19 patients and its correlation with inflammatory markers. Sci. Rep. 2020, 10, 20191. [CrossRef]

100. Macaya, F.; Espejo Paeres, C.; Valls, A.; Fernández-Ortiz, A.; González Del Castillo, J.; Martín-Sánchez, F.J.; Runkle, I.; Rubio Herrera, M. Interaction between age and vitamin D deficiency in severe COVID-19 infection. Nutr. Hosp. 2020, 37, 1039-1042. [CrossRef]

101. Mendy, A.; Apewokin, S.; Wells, A.A.; Morrow, A.L. Factors Associated with Hospitalization and Disease Severity in a Racially and Ethnically Diverse Population of COVID-19 Patients. medRxiv 2020. [CrossRef]

102. Panagiotou, G.; Tee, S.A.; Ihsan, Y.; Athar, W.; Marchitelli, G.; Kelly, D.; Boot, C.S.; Stock, N.; Macfarlane, J.; Martineau, A.R.; et al. Low serum 25-hydroxyvitamin D (25[OH]D) levels in patients hospitalized with COVID-19 are associated with greater disease severity. Clin. Endocrinol. 2020, 93, 508-511. [CrossRef]

103. Barassi, A.; Pezzilli, R.; Mondoni, M.; Rinaldo, R.F.; DavĪ, M.; Cozzolino, M.; Melzi D’Eril, G.V.; Centanni, S. Vitamin D in severe acute respiratory syndrome coronavirus 2 (SARS-CoV-2) patients with non-invasive ventilation support. Panminerva Med. 2021. [CrossRef]

104. Seal, K.; Bertenthal, D.; Carey, E. Impact of Low Vitamin D Levels on COVID19-Related Hospitalization and Mortality: Results From a National Cohort of Veterans Affairs Patients. Glob. Adv. Health Med. 2021, 10, 1-64. [CrossRef] 
105. Gönen, M.S.; Alaylığlu, M.; Durcan, E.; Özdemir, Y.; Şahin, S.; Konukoğlu, D.; Nohut, O.K.; Ürkmez, S.; Küçükece, B.; Balkan, İ.; et al. Rapid and Effective Vitamin D Supplementation May Present Better Clinical Outcomes in COVID-19 (SARS-CoV-2) Patients by Altering Serum INOS1, IL1B, IFNg, Cathelicidin-LL37, and ICAM1. Nutrients 2021, 13, 4047. [CrossRef]

106. Loucera, C.; Peña-Chilet, M.; Esteban-Medina, M.; Muñoyerro-Muñiz, D.; Villegas, R.; Lopez-Miranda, J.; Rodriguez-Baño, J.; Túnez, I.; Bouillon, R.; Dopazo, J.; et al. Real world evidence of calcifediol or vitamin D prescription and mortality rate of COVID-19 in a retrospective cohort of hospitalized Andalusian patients. Sci. Rep. 2021, 11, 23380. [CrossRef]

107. Jevalikar, G.; Mithal, A.; Singh, A.; Sharma, R.; Farooqui, K.J.; Mahendru, S.; Dewan, A.; Budhiraja, S. Lack of association of baseline 25-hydroxyvitamin D levels with disease severity and mortality in Indian patients hospitalized for COVID-19. Sci. Rep. 2021, 11, 6258. [CrossRef] [PubMed]

108. Hernández, J.L.; Nan, D.; Fernandez-Ayala, M.; García-Unzueta, M.; Hernández-Hernández, M.A.; López-Hoyos, M.; MuñozCacho, P.; Olmos, J.M.; Gutiérrez-Cuadra, M.; Ruiz-Cubillán, J.J.; et al. Vitamin D Status in Hospitalized Patients with SARS-CoV-2 Infection. J. Clin. Endocrinol. Metab. 2021, 106, e1343-e1353. [CrossRef]

109. Lohia, P.; Nguyen, P.; Patel, N.; Kapur, S. Exploring the link between vitamin D and clinical outcomes in COVID-19. Am. J. Physiol. Metab. 2021, 320, E520-E526. [CrossRef] [PubMed]

110. Pouramini, A.; Kafi, F.; Hassanzadeh, S. Vitamin D and COVID-19 infection; recent findings. J. Ren. Endocrinol. 2021, 7, e19. [CrossRef]

111. Dayal, D.; Gupta, B.M.; Surulinathi, M.; Nanda, P. COVID-19 and Vitamin D Deficiency: A Scientometric Assessment of Global Publications during 2020-21. J. Young Pharm. 2021, 13, s89-s94. [CrossRef]

112. Filep, J.G.; Delalandre, A.; Payette, Y.; Földes-Filep, E. Glucocorticoid receptor regulates expression of L-selectin and CD11/CD18 on human neutrophils. Circulation 1997, 96, 295-301. [CrossRef] [PubMed]

113. Burton, J.L.; Kehrli, M.E., Jr.; Kapil, S.; Horst, R.L. Regulation of L-selectin and CD18 on bovine neutrophils by glucocorticoids: Effects of cortisol and dexamethasone. J. Leukoc. Biol. 1995, 57, 317-325. [CrossRef] [PubMed]

114. Weber, P.S.; Toelboell, T.; Chang, L.C.; Tirrell, J.D.; Saama, P.M.; Smith, G.W.; Burton, J.L. Mechanisms of glucocorticoid-induced down-regulation of neutrophil L-selectin in cattle: Evidence for effects at the gene-expression level and primarily on blood neutrophils. J. Leukoc. Biol. 2004, 75, 815-827. [CrossRef]

115. Smith, C.W. Endothelial adhesion molecules and their role in inflammation. Can. J. Physiol. Pharmacol. 1993, 71, 76-87. [CrossRef] [PubMed]

116. Van Eeden, S.; Miyagashima, R.; Haley, L.; Hogg, J.C. L-selectin expression increases on peripheral blood polymorphonuclear leukocytes during active marrow release. Am. J. Respir. Crit. Care Med. 1995, 151, 500-507. [CrossRef]

117. Török, C.; Lundahl, J.; Hed, J.; Lagercrantz, H. Diversity in regulation of adhesion molecules (Mac-1 and L-selectin) in monocytes and neutrophils from neonates and adults. Arch. Dis. Child. 1993, 68, 561-565. [CrossRef]

118. Cronstein, B.N.; Kimmel, S.C.; Levin, R.I.; Martiniuk, F.; Weissmann, G. A mechanism for the antiinflammatory effects of corticosteroids: The glucocorticoid receptor regulates leukocyte adhesion to endothelial cells and expression of endothelialleukocyte adhesion molecule 1 and intercellular adhesion molecule 1. Proc. Natl. Acad. Sci. USA 1992, 89, 9991-9995. [CrossRef] [PubMed]

119. Tahir, N.; Zahra, F. Neutrophilia. StatPearls Publishing Copyright ${ }^{\circledR}$ 2021. In StatPearls; StatPearls Publishing LLC: Treasure Island, FL, USA, 2021.

120. Sterne, J.A.C.; Murthy, S.; Diaz, J.V.; Slutsky, A.S.; Villar, J.; Angus, D.C.; Annane, D.; Azevedo, L.C.P.; Berwanger, O.; Cavalcanti, A.B.; et al. Association between Administration of Systemic Corticosteroids and Mortality among Critically Ill Patients with COVID-19: A Meta-analysis. JAMA 2020, 324, 1330-1341. [CrossRef] [PubMed]

121. Cohn, B.A.; Cirillo, P.M.; Murphy, C.C.; Krigbaum, N.Y.; Wallace, A.W. SARS-CoV-2 vaccine protection and deaths among US veterans during 2021. Science 2021, eabm0620. [CrossRef]

122. Mazess, R.B.; Bischoff-Ferrari, H.A.; Dawson-Hughes, B. Vitamin D: Bolus Is Bogus-A Narrative Review. JBMR Plus 2021, e10567. [CrossRef]

123. Martineau, A.R.; Jolliffe, D.A.; Greenberg, L.; Aloia, J.F.; Bergman, P.; Dubnov-Raz, G.; Esposito, S.; Ganmaa, D.; Ginde, A.A.; Goodall, E.C.; et al. Vitamin D supplementation to prevent acute respiratory infections: Individual participant data meta-analysis. Health Technol. Assess. 2019, 23, 1-44. [CrossRef] [PubMed]

124. Griffin, G.; Hewison, M.; Hopkin, J.; Kenny, R.A.; Quinton, R.; Rhodes, J.; Subramanian, S.; Thickett, D. Perspective: Vitamin D supplementation prevents rickets and acute respiratory infections when given as daily maintenance but not as intermittent bolus: Implications for COVID-19. Clin. Med. 2021, 21, e144-e149. [CrossRef]

125. Ketha, H.; Thacher, T.D.; Oberhelman, S.S.; Fischer, P.R.; Singh, R.J.; Kumar, R. Comparison of the effect of daily versus bolus dose maternal vitamin $\mathrm{D}(3)$ supplementation on the 24,25 -dihydroxyvitamin $\mathrm{D}(3)$ to 25 -hydroxyvitamin $\mathrm{D}(3)$ ratio. Bone 2018, 110 , 321-325. [CrossRef] [PubMed]

126. Burt, L.A.; Billington, E.O.; Rose, M.S.; Raymond, D.A.; Hanley, D.A.; Boyd, S.K. Effect of High-Dose Vitamin D Supplementation on Volumetric Bone Density and Bone Strength: A Randomized Clinical Trial. JAMA 2019, 322, 736-745. [CrossRef] [PubMed]

127. Klinger, M.; Alexiewicz, J.M.; Linker-Israeli, M.; Pitts, T.O.; Gaciong, Z.; Fadda, G.Z.; Massry, S.G. Effect of parathyroid hormone on human T cell activation. Kidney Int. 1990, 37, 1543-1551. [CrossRef]

128. Shurtz-Swirski, R.; Shkolnik, T.; Shasha, S.M. Parathyroid hormone and the cellular immune system. Nephron 1995, 70, 21-24. [CrossRef] [PubMed] 
129. Lewin, E.; Ladefoged, J.; Brandi, L.; Olgaard, K. Parathyroid hormone dependent T cell proliferation in uremic rats. Kidney Int. 1993, 44, 379-384. [CrossRef] [PubMed]

130. Geara, A.S.; Castellanos, M.R.; Bassil, C.; Schuller-Levis, G.; Park, E.; Smith, M.; Goldman, M.; Elsayegh, S. Effects of parathyroid hormone on immune function. Clin. Dev. Immunol. 2010, 2010, 418695. [CrossRef] [PubMed]

131. Hsu, S.; Prince, D.K.; Williams, K.; Allen, N.B.; Burke, G.L.; Hoofnagle, A.N.; Li, X.; Liu, K.J.; McClelland, R.L.; Michos, E.D.; et al. Clinical and biomarker modifiers of vitamin D treatment response: The multi-ethnic study of atherosclerosis. Am. J. Clin. Nutr. 2021. [CrossRef]

132. Leaf, D.E.; Ginde, A.A. Vitamin D3 to Treat COVID-19: Different Disease, Same Answer. JAMA 2021, 325, 1047-1048. [CrossRef] [PubMed]

133. Hung, A.; Lee, K.M.; Lynch, J.A.; Li, Y.; Poonnen, P.; Efimova, O.V.; Hintze, B.J.; Buckingham, T.; Yong, C.; Seal, B.; et al. Chemoradiation treatment patterns among United States Veteran Health Administration patients with unresectable stage III non-small cell lung cancer. BMC Cancer 2021, 21, 824. [CrossRef] [PubMed]

134. Razjouyan, J.; Helmer, D.A.; Lynch, K.E.; Hanania, N.A.; Klotman, P.E.; Sharafkhaneh, A.; Amos, C.I. Smoking Status and Factors associated with COVID-19 In-hospital Mortality among U.S. Veterans. Nicotine Tob. Res. 2021. [CrossRef]

135. Griffith, G.J.; Morris, T.T.; Tudball, M.J.; Herbert, A.; Mancano, G.; Pike, L.; Sharp, G.C.; Sterne, J.; Palmer, T.M.; Davey Smith, G.; et al. Collider bias undermines our understanding of COVID-19 disease risk and severity. Nat. Commun. 2020, 11, 5749. [CrossRef]

136. Song, R.J.; Ho, Y.L.; Schubert, P.; Park, Y.; Posner, D.; Lord, E.M.; Costa, L.; Gerlovin, H.; Kurgansky, K.E.; Anglin-Foote, T.; et al. Phenome-wide association of 1809 phenotypes and COVID-19 disease progression in the Veterans Health Administration Million Veteran Program. PLoS ONE 2021, 16, e0251651. [CrossRef]

137. Escobar, G.J.; Adams, A.S.; Liu, V.X.; Soltesz, L.; Chen, Y.I.; Parodi, S.M.; Ray, G.T.; Myers, L.C.; Ramaprasad, C.M.; Dlott, R.; et al. Racial Disparities in COVID-19 Testing and Outcomes: Retrospective Cohort Study in an Integrated Health System. Ann. Intern. Med. 2021, 174, 786-793. [CrossRef]

138. Pearce, N.; Rhodes, S.; Stocking, K.; Pembrey, L.; van Veldhoven, K.; Brickley, E.B.; Robertson, S.; Davoren, D.; Nafilyan, V.; Windsor-Shellard, B.; et al. Occupational differences in COVID-19 incidence, severity, and mortality in the United Kingdom: Available data and framework for analyses. Wellcome Open Res. 2021, 6, 102. [CrossRef] [PubMed]

139. Vitamin D: Fact Sheet for Consumers. Available online: https://ods.od.nih.gov/factsheets/VitaminD-Consumer/ (accessed on 29 November 2021).

140. Aboumrad, M.; Shiner, B.; Riblet, N.; Huizenga, H.; Neupane, N.; Young-Xu, Y. Trends in COVID-19 cases and clinical management in Veterans Health Administration medical facilities: A national cohort study. PLoS ONE 2021, 16, e0246217. [CrossRef] [PubMed]

141. Ioannou, G.N.; O’Hare, A.M.; Berry, K.; Fan, V.S.; Crothers, K.; Eastment, M.C.; Locke, E.; Green, P.; Shah, J.A.; Dominitz, J.A Trends over time in the risk of adverse outcomes among patients with SARS-CoV-2 infection. Clin. Infect. Dis. 2021. [CrossRef] [PubMed]

142. Tran, B.X.; Vu, G.T.; Le, H.T.; Pham, H.Q.; Phan, H.T.; Latkin, C.A.; Ho, R.C. Understanding health seeking behaviors to inform COVID-19 surveillance and detection in resource-scarce settings. J. Glob. Health 2020, 10, 0203106. [CrossRef]

143. Hoerster, K.D.; Lehavot, K.; Simpson, T.; McFall, M.; Reiber, G.; Nelson, K.M. Health and health behavior differences: U.S. Military, veteran, and civilian men. Am. J. Prev. Med. 2012, 43, 483-489. [CrossRef]

144. Maloney, S.R.; Goolkasian, P. Low Vitamin D States Observed in U.S. Marines and Navy Sailors with Early Multi-Symptom Illness. Biomolecules 2020, 10, 1032. [CrossRef] [PubMed]

145. Devoto, C.; Arcurio, L.; Fetta, J.; Ley, M.; Rodney, T.; Kanefsky, R.; Gill, J. Inflammation Relates to Chronic Behavioral and Neurological Symptoms in Military Personnel with Traumatic Brain Injuries. Cell Transplant. 2017, 26, 1169-1177. [CrossRef] [PubMed]

146. Fogleman, S.A.; Janney, C.; Cialdella-Kam, L.; Flint, J.H. Vitamin D Deficiency in the Military: It's Time to Act! Mil. Med. 2021 [CrossRef] [PubMed]

147. Kojima, G.; Tamai, A.; Masaki, K.; Gatchell, G.; Epure, J.; China, C.; Ross, G.W.; Petrovitch, H.; Tanabe, M. Prevalence of vitamin $\mathrm{D}$ deficiency and association with functional status in newly admitted male veteran nursing home residents. J. Am. Geriatr. Soc. 2013, 61, 1953-1957. [CrossRef] [PubMed]

148. Al-Anouti, F.; Mousa, M.; Karras, S.N.; Grant, W.B.; Alhalwachi, Z.; Abdel-Wareth, L.; Uddin, M.; Alkaabi, N.; Tay, G.K.; Mahboub, B.; et al. Associations between Genetic Variants in the Vitamin D Metabolism Pathway and Severity of COVID-19 among UAE Residents. Nutrients 2021, 13, 3680. [CrossRef]

149. Speeckaert, M.M.; Speeckaert, R.; Delanghe, J.R. Vitamin D Sufficiency and COVID-19: Is Vitamin D Binding Protein (and Its Polymorphism) the Missing Link? Endocr. Pract. 2021, 27, 645. [CrossRef] [PubMed]

150. Amrein, K.; Papinutti, A.; Mathew, E.; Vila, G.; Parekh, D. Vitamin D and critical illness: What endocrinology can learn from intensive care and vice versa. Endocr. Connect. 2018, 7, R304-R315. [CrossRef] [PubMed] 